\title{
PERFIL IMIGRATÓRIO DO ESTADO DO RIO GRANDE DO SUL NAS PRIMEIRAS DÉCADAS DO SÉCULO XXI
}

\author{
Roberto Rodolfo Georg Uebel ${ }^{1}$ \\ Aldomar Arnaldo Rückert ${ }^{2}$
}

Resumo: As migraçóes internacionais para o Brasil têm experimentado crescimento exponencial nas últimas duas décadas - entre 2010 e 2015 -, com migrantes vindo predominantemente de países latino-americanos, da Europa ocidental e do leste da Ásia. Dentro do território brasileiro, o Estado que mais vem se destacando em números absolutos de imigrantes nos últimos anos é o Rio Grande do Sul, estrategicamente localizado na parte mais meridional do país e fronteiriço com a Argentina e o Uruguai. O Estado está inserido nas rotas migratórias internacionais entre o sudeste asiático, Oceania, América do Sul, África e Europa, dadas as suas conexôes aéreas e marítimas. Este artigo analisa o perfil social, demográfico e laboral das migraçóes internacionais para o Rio Grande do Sul nas últimas duas décadas, usando-se a abordagem das redes migratórias, além dos instrumentais da cartografia temática. Esta pesquisa igualmente está inserida no âmbito de um projeto maior sobre as transfronteirizaçóes na América do Sul com apoio da CAPES-Pró-Defesa, que têm entre suas dinâmicas a reconfiguração das fronteiras a partir dos novos fluxos imigratórios, especialmente na Bacia do Prata - uma das regióes de análise do artigo - e no arco norte das fronteiras brasileiras. Assim, por meio desses processos de transfronteirizaçóes, os fluxos imigratórios analisados também integram a agenda de transformaçôes territoriais do Brasil e, mais especificamente, do Rio Grande do Sul, tendo em consideraçáo as questôes de mobilidade laboral, trabalho e dinâmicas sociaisterritoriais. Ademais, o artigo analisa o perfil e a motivação dos migrantes de cada continente em direção ao Estado e suas repercussóes sociais e econômicas. Por fim, este estudo é cuncluído com notas e projeçóes dos fluxos migratórios para a atualidade e reminiscências das migraçóes para o Brasil em geral. É um artigo que deseja projetar a discussão sobre as migraçóes contemporâneas para o Brasil e para o Rio Grande do Sul, incorporando discussóes da demografia, geografia e relaçóes internacionais, em um momento de profundas transformaçóes políticas, econômicas, ideológicas e sociais (inclusive de direitos humanos) no campo das migraçóes e políticas migratórias no Estado brasileiro, alicerçado em bases questionáveis e indagadoras sobre os rumos da gestão das migrações e refúgio no âmbito da administração federal interina e dos próprios fluxos imigratórios analisados pela

1 Doutorando do Programa de Pós-Graduação em Estudos Estratégicos Internacionais da Universidade Federal do Rio Grande do Sul. Pesquisador do Laboratório Estado e Território (LABETER/UFRGS).roberto.uebel@ufrgs.br

2 Professor do Departamento de Geografia e dos Programas de Pós-Graduação em Geografia e Planejamento Urbano e Regional da Universidade Federal do Rio Grande do Sul. PesquisadorLíder do Laboratório Estado e Território (LABETER/UFRGS). aldomar.ruckert@gmail.com 
pesquisa. Por fim, o estudo lança mão de aportes e bases para futuras discussôes sobre as migraçóes e mobilidades transfronteiriças não apenas no Rio Grande do Sul, mas em todo o arco sul das fronteiras brasileiras e mercosulinas.

Palavras-chave: Imigraçóes. Rio Grande do Sul. Perfil. Século XXI.

\title{
IMMIGRATORY PROFILE OF THE STATE OF RIO GRANDE DO SUL IN THE FIRST DECADES OF THE TWENTY-FIRST CENTURY
}

\begin{abstract}
The international migrations to Brazil have experienced exponential growth over the past two decades, with migrants coming mainly from Latin American neighbouring countries, Western Europe and East Asia. Inside the Brazilian territory the state that most has been highlighted in absolute numbers of immigrants in recent years is Rio Grande do Sul, strategically located in the southernmost part of the country and bordering Argentina and Uruguay. The state is inserted in international migration routes between Southeast Asia, Oceania, South America and Africa and Europe, given its air and maritime connections. This article analyses the social, demographic and labour profile of international migrations to Rio Grande do Sul in the last two decades, using the methodological approach of migratory networks in addition to the instrumentals of thematic cartography. This research is also included in the scope of a larger research project on transborderings in South America supported by CAPES-Pró-Defesa, which has among its dynamics, the reconfiguration of borders based on the new migratory flows, especially in the La Plata Basin - one of the analysis regions of the article - and in the North Arch of Brazilian borders. Thus, through these transborderings processes, the examined immigration flows also integrate the agenda of territorial transformations of Brazil and, more specifically, of Rio Grande do Sul, taking into consideration the issues of worker mobility, employment and social-territorial dynamics. Moreover, the article analyses the profile and motivation of migrants from each continent towards the state and their social and economic repercussions. Finally, the article concludes with notes and projections of migration flows to the present days and reminiscences of migrations to Brazil in general. This is an article that aims to project the discussion on contemporary migration to Brazil and Rio Grande do Sul, by incorporating discussions from the Demography, Geography and International Relations, in a moment of deep political, economic, ideological and social (including human rights) changes in the field of migration and migration policies in the Brazilian state, based on inquiring and questionable bases about the directions of the management of migration and refuge under the interim Federal Administration and the proper immigration flows analysed by the article. At last, the article promotes contributions and basis for future discussions on migration and cross-border mobility not only in Rio Grande do Sul, but throughout the South Arch of Brazilian borders and MERCOSUR borderlands.
\end{abstract}

Keywords: Migrations. Rio Grande do Sul. Profile. Twenty-first century.

\section{Introduçáo}

As primeiras migrações internacionais que ocorreram para o Rio Grande do Sul nos séculos XIX e XX, compostas predominantemente por alemães, italianos, espanhóis e poloneses, além de outras nacionalidades, tinham o caráter de "povoar o Sul do Brasil, produzir alimentos em pequenas propriedades de terra e, em menor 
escala, promover um branqueamento da população em função da escravidão" (GERTZ apud ROLLSING; TREZZI, 2014) e eram fomentadas pelo governo brasileiro da época (período que compreende desde o Império até o começo da República Velha).

O panorama contemporâneo da imigração no Estado é, todavia, diferente e com modus operandi completamente distinto e único: os imigrantes em sua maioria possuem formação superior, são homens, imigram sozinhos e vêm por conta própria (UEBEL, 2015). Embora alguns autores ponderem que o fenômeno que se verifica tanto no Brasil como no Rio Grande do Sul se trate de uma "onda imigratória", ou seja, que deverá se estabilizar em médio ou longo prazo, a análise gráfica e cartográfica nas próximas seções permite uma inferência distinta.

Trata-se agora de "um fluxo migratório que passa a incluir o Brasil" (MEZZANOTTI apud ROLLSING; TREZZI, 2014) e, por conseguinte, o Rio Grande do Sul na agenda das migrações internacionais neste começo de século XXI, consolidando-os como destino principal e polo de atração nos próximos anos.

\section{Variaçáo da imigraçáo no Rio Grande do Sul entre 2000, 2010 e 2014}

Se os dados verificados em pesquisas recentes sobre a imigração para o Brasil, como a de Uebel (2015), já mostravam potencial crescimento dos fluxos imigratórios em direção ao país entre os anos de 2000, 2010 e 2014, quando analisamos a evolução desses dados ${ }^{3}$ para o Rio Grande do Sul, percebe-se aumento expressivo não apenas na quantidade de novos imigrantes, mas também no aumento das nacionalidades que compõem esse panorama imigratório.

O Gráfico 1 apresenta a evolução do número (estoque) de imigrantes no Estado do Rio Grande do Sul nos anos 2000 e a partir de 2007 até 2014.

3 Dados disponíveis para consulta e download na página <https://www.dropbox.com/sh/ fg7dq7xq6gj2049/AAC0bhS-eurv0vpTHSeBfjIta?dl=0>. Os dados foram obtidos pelos autores por meio da Lei de Acesso à Informação. 
Gráfico 1 - Série histórica do número de imigrantes no Rio Grande do Sul - 2000, 2007-2014

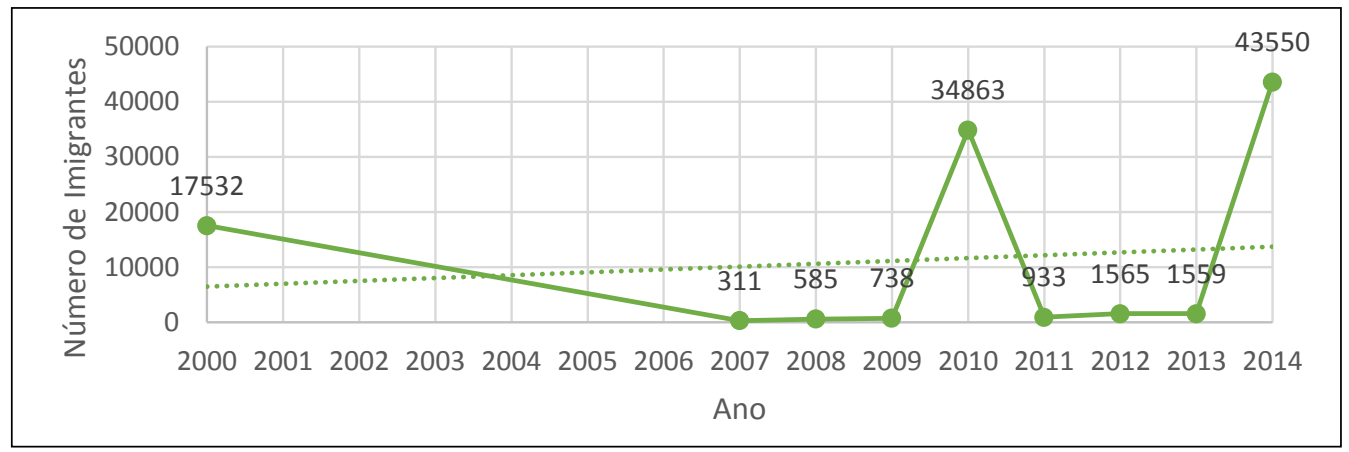

Fonte: Instituto Brasileiro de Geografia e Estatística, Departamento de Polícia Federal, Ministério do Trabalho e Emprego - dados compilados e tabulados pelos autores.

Observa-se, portanto, que o comportamento dos fluxos imigratórios para o Estado apresenta nos anos de mudança - pontos de inflexão - um crescimento acima da própria linha de tendência, que previa migration incomes na casa dos cinco a 15 mil imigrantes no período de 15 anos.

Percebe-se assim um boom imigratório em 2010 e 2014. É curioso observar que os estoques anuais, especificamente nos anos de 2000, 2010 e 2014, tiveram um salto quantitativo muito expressivo, apresentando crescimento de $198,8 \%$ entre 2000 e 2010 e de $125 \%$ entre 2010 e 2014, ou seja, cresceu-se em quatro anos o número de imigrantes no Rio Grande do Sul quase o que se levou em uma década.

Esses números são bem expressivos se compararmos com a séries históricas não apenas do Rio Grande do Sul, mas também de outros Estados, que também experimentam um grande aporte de imigrantes em seus territórios a partir de 2010, superando-se até mesmo São Paulo, considerado então o principal destino das migrações internacionais no Brasil, que teve crescimento de $117 \%$ entre 2000 e 2010 (PREFEITURA DE SÃO PAULO, 2012).

Apesar disso, a linha de tendência do gráfico anterior apresenta crescimento estável estimado ao longo do período e também para os próximos anos de não mais que dois mil novos imigrantes por ano, como bem se percebe a partir de 2010 .

Um estudo recente da Organização Internacional para as Migrações, da qual o Brasil é partícipe, aponta as motivações para este fluxo "Norte-Sul" e confirma a hipótese desta pesquisa:

O elevado desemprego entre os jovens nos países da Europa possui também um impacto sobre as taxas de emigração. Mas nem toda a migração NorteSul está ligada aos fatores econômicos e de recessão. Outras razões para a migração Norte-Sul incluem a globalização e a mudança de empresas do Norte para o Sul. De acordo com o "2012 Global Mobility Survey Report", $47 \%$ das organizações registraram crescimento de missões internacionais no último ano, abastecido pela explosiva expansão dos mercados emergentes, em 
particular a China (BRAZIER, 2012). Um número crescente de estudantes está optando por buscar educação no exterior - e cada vez mais eles estão optando por fazê-lo fora dos países de destino tradicionais (OECD, 2010). Novos países no Sul que surgiram como destinos populares para estudantes internacionais incluem a China, Malásia e África do Sul (UNESCO, 2012). A migração de aposentados também é um fator que está contribuindo para o aumento na migração Norte-Sul (LACKZO; BRIAN, 2013, tradução nossa).

Observam-se nessa citação justamente os países que possuem considerável participação no ranking das nacionalidades de imigrantes no último estoque imigratório calculado para o Rio Grande do Sul, que compreende os anos de 2007 a 2014 e está representado na Tabela 1.

Tabela 1. Ranking de grupos imigratórios no Rio Grande do Sul por nacionalidade - estoque total de 2007 a 2014

\begin{tabular}{|c|c|c|}
\hline Nacionalidade & Total por nacionalidade & Ranking \\
\hline Uruguai & 36.299 & $1^{\circ}$ \\
\hline Argentina & 11.792 & $2^{\circ}$ \\
\hline Portugal & 5.614 & $3^{\circ}$ \\
\hline Itália & 5.002 & $4^{\circ}$ \\
\hline Alemanha & 4.564 & $5^{\circ}$ \\
\hline Estados Unidos & 3.607 & $6^{\circ}$ \\
\hline Chile & 2.793 & $7^{\circ}$ \\
\hline Espanha & 2.681 & $8^{\circ}$ \\
\hline Japão & 2.578 & $9^{\circ}$ \\
\hline Haiti & 2.517 & $10^{\circ}$ \\
\hline China & 2.441 & $11^{\circ}$ \\
\hline Paraguai & 1.805 & $12^{\circ}$ \\
\hline Polônia & 1.682 & $13^{\circ}$ \\
\hline Colômbia & 1.445 & $14^{\circ}$ \\
\hline Peru & 1.407 & $15^{\circ}$ \\
\hline Jordânia & 1.096 & $16^{\circ}$ \\
\hline Bolívia & 1.021 & $17^{\circ}$ \\
\hline Reino Unido & 943 & $18^{\circ}$ \\
\hline França & 906 & $19^{\circ}$ \\
\hline Rússia & 836 & $20^{\circ}$ \\
\hline Holanda & 539 & $21^{\circ}$ \\
\hline Senegal & 536 & $22^{\circ}$ \\
\hline
\end{tabular}




\begin{tabular}{lcc}
\hline Nacionalidade & Total por nacionalidade & Ranking \\
\hline Cuba & 466 & $23^{\circ}$ \\
Canadá & 423 & $24^{\circ}$ \\
México & 421 & $25^{\circ}$ \\
Líbano & 420 & $26^{\circ}$ \\
Coreia do Sul & 400 & $27^{\circ}$ \\
Grécia & 373 & $28^{\circ}$ \\
Áustria & 371 & $29^{\circ}$ \\
Angola & 366 & $30^{\circ}$ \\
\hline
\end{tabular}

Fonte: Instituto Brasileiro de Geografia e Estatística, Departamento de Polícia Federal, Ministério do Trabalho e Emprego - dados compilados e tabulados pelos autores.

Tem-se, posto isso, que os principais grupos imigratórios no Rio Grande do Sul coincidem em certo nível com a própria realidade escalar nacional, ao passo que no RS os haitianos, por exemplo, correspondem ao décimo maior grupo imigratório e no ranking brasileiro estão apenas na $19^{\mathrm{a}}$ posição.

Apesar disso, angolanos e senegaleses aparecem timidamente no ranking estadual e os ganeses, que já foram destaque na mídia sul-rio-grandense, aparecem apenas na $92^{\mathrm{a}}$ posição. Esse fato reafirma a hipótese de que a percepção da presença dos imigrantes africanos e haitianos no Estado deu-se por outros motivos, entre os quais raciais, étnicos e subjetivamente xenofóbicos, já que a presença de outros grupos é numericamente maior. Apresenta-se então o Gráfico 2, do período que vai de 2007 a 2014, que sintetiza a participação dos principais grupos imigratórios na composição populacional do Rio Grande do Sul.

Gráfico 2 - Representação percentual dos dez maiores grupos imigratórios no Rio Grande do Sul - 2007-2014

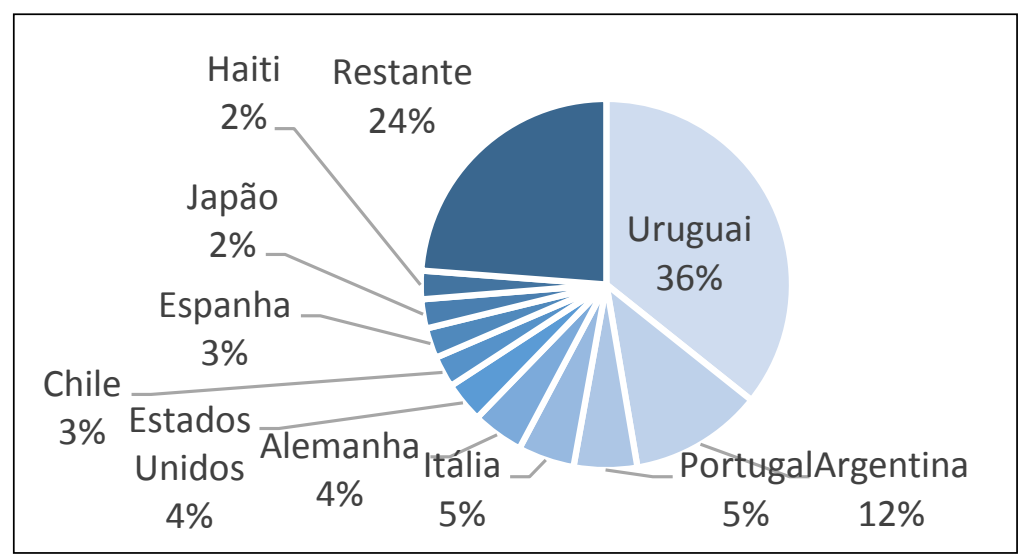

Fonte: Instituto Brasileiro de Geografia e Estatística, Departamento de Polícia Federal, Ministério do Trabalho e Emprego - dados compilados e tabulados pelos autores. 
Por ora, percebe-se origem étnica predominantemente caucasiana da composição imigratória no Rio Grande do Sul no período analisado, isto é, imigrantes de cor branca representam $74 \%$ e haitianos apenas $2 \%$ no espectro dos dez maiores grupos imigratórios. A indagação que se apresenta é o porquê de apenas esses $2 \%$ serem destaque - muitas vezes de forma negativa - na imprensa e no discurso da sociedade, que aparentemente apresentam desconhecimento dos demais grupos imigratórios presentes no Estado. ${ }^{4}$

No cômputo total do estoque de imigração no Rio Grande do Sul, os dados apontam que há, no período de 2007 a 2014, o número de 84 mil imigrantes - mais precisamente 84.104 cidadãos imigrados - no Estado, população que representa $4,5 \%$ dos imigrantes em território brasileiro e aproximadamente $0,8 \%$ da população do Rio Grande do Sul. O mapa da Figura 1 traduz a origem desses imigrantes dadas as suas nacionalidades.

4 Dentre as demonstrações públicas desse desconhecimento ou xenofobismo subjetivo, destacamos a seguinte fala proferida por um vereador da cidade de Caxias do Sul: "O vereador X.Y. tornou-se alvo de críticas nas redes sociais e teve de dar explicações ontem após uma declaração polêmica na Câmara de Caxias do Sul, na Serra. Na terça-feira [18 de março de 2014], no plenário, o parlamentar disse que a vinda de senegaleses e haitianos não traz benefícios ao Brasil nem ao município, e sim mais pobreza. 'Muitos senegaleses e haitianos não respeitam filas nas unidades de saúde, ou ocupam assentos reservados a idosos e gestantes. [...] A cultura e as maneiras deles são muito diferentes das nossas', disse X.Y." (INSTITUTO HUMANITAS UNISINOS, 2014) [Omitiram-se os nomes para preservar a identidade do autor da frase]. 
Figura 1 - Estoque de imigrantes no Rio Grande do Sul de acordo com sua nacionalidade - 2007-2014

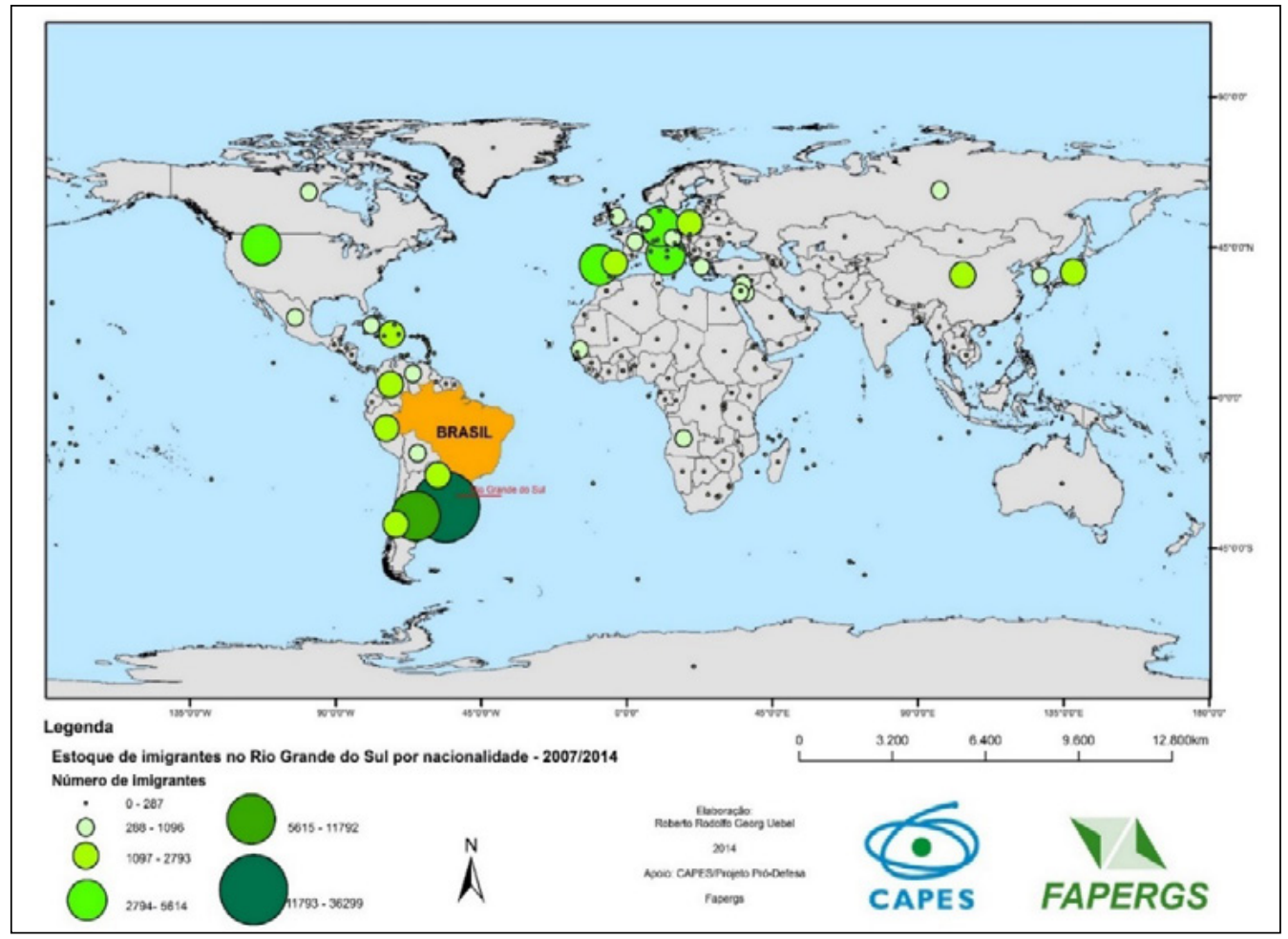

Fonte: elaborado pelos autores.

O mapa da Figura 1 mostra, dividindo em seis classes as nacionalidades dos imigrantes, uma tendência de concentração continental de procedência dos imigrantes, isto é, eles provêm de nações próximas, dividindo-os em blocos: 1- América do Sul, 2- Estados Unidos e Caribe, 3- Europa, 4- Extremo Oriente.

Nas análises por continente na última seção deste artigo, discorreremos sobre a procedência e motivações dos principais grupos imigratórios desses recortes territoriais, além de ponderar sua participação no estoque atual de imigrantes do Rio Grande do Sul.

A propósito de auxílio instrumental na inferência das variações estatísticas do número de imigrantes no Rio Grande do Sul, elaborou-se o Gráfico $3 \mathrm{com}$ o ranking das 20 nacionalidades de imigrantes (excluindo-se as duas primeiras, Uruguai e Argentina, para explicitar o crescimento dos demais grupos imigratórios) e sua evolução, tendo como base de comparação o ano de 2014 em relação aos anos de 2010 e 2000. 
Gráfico 3 - Variação de imigrantes no Rio Grande do Sul por nacionalidade 2014,2010 e 2000

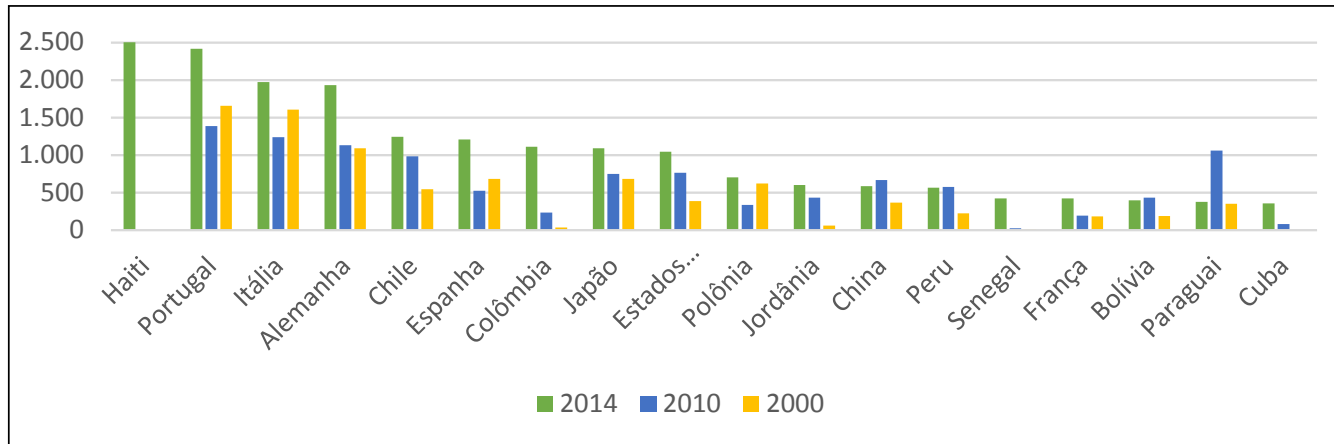

Fonte: Instituto Brasileiro de Geografia e Estatística, Departamento de Polícia Federal, Ministério do Trabalho e Emprego - dados compilados e tabulados pelos autores.

Os dados apresentados no Gráfico 3 expõem evolução crítica no quadro imigratório sul-rio-grandense, ao passo que nacionalidades antes não representadas, como os próprios haitianos, senegaleses e cubanos, passam a ocupar as primeiras posições no ranking imigratório de 2014, por exemplo.

Os únicos três casos em que houve diminuição dos fluxos imigratórios para o Rio Grande do Sul foram os paraguaios, peruanos e chineses, sem uma indicação conclusiva do motivo da diminuição dessas imigrações, ao passo que na escala nacional brasileira, apesar de perderem posições no ranking de representatividade das imigrações, eles mantiveram o crescimento do número de imigrantes nos últimos anos.

Assim, nas próximas três seções analisa-se o panorama das migrações internacionais com destino ao Estado do Rio Grande do Sul nos anos de 2000, 2010 e no biênio 2013-2014, registrando a evolução desses fluxos e projeções para o médio prazo, isto é, até o fim desta década, com base na hipótese de que os fluxos de haitianos e africanos - no caso senegaleses - deverão tornar-se estáveis nos próximos anos até atingirem um ponto máximo e seguirem em declínio vis-àvis às oportunidades de emprego no Estado e desempenho da economia estadual e brasileira, ou seja, sua atratividade à decisão de imigrar.

\section{Perfil imigratório do Rio Grande do Sul no ano 2000: o Estado das imigraçóes tradicionais}

No ano 2000, o Estado do Rio Grande do Sul seguia o padrão da escala brasileira, isto é, possuía baixo estoque de imigrantes e era pouco atrativo aos novos imigrantes em virtude de seu fraco desempenho econômico na época. Soma-se a isso o fato de que até aquela década os fluxos imigratórios internacionais "NorteSul" eram nulos ou quase inexistentes e dentro do Brasil a preferência era pelos 
Estados da região Sudeste, face o seu crescimento econômico e oportunidades de emprego.

Com população de apenas 17,6 mil imigrantes, estes correspondiam apenas a $0,17 \%$ da população total do Estado em $2000^{5}$, um número menor que a população da maioria dos municípios gaúchos. Além disso, os grupos imigratórios eram dispersos por todas as regiões do RS, sem uma concentração, como no caso dos haitianos e senegaleses quase duas décadas depois.

Nesse sentido, o Gráfico 4 mostra que a composição dos dez maiores grupos imigratórios no Rio Grande do Sul no ano 2000 era restrita as grupos nacionais que imigraram e colonizaram o Estado um século antes.

Gráfico 4 - Representação percentual dos dez maiores grupos imigratórios no Rio Grande do Sul no ano 2000

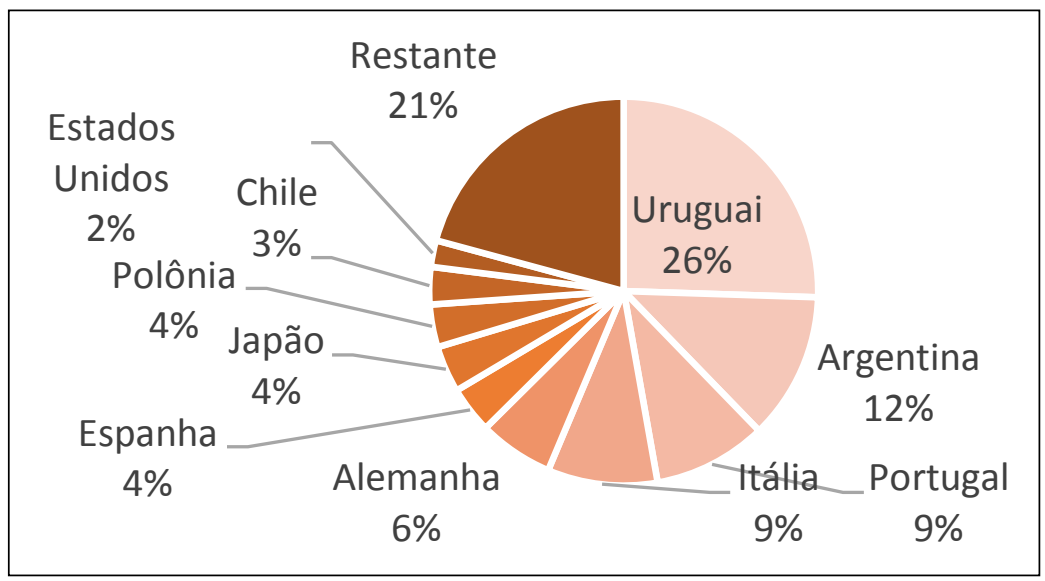

Fonte: Instituto Brasileiro de Geografia e Estatística, Departamento de Polícia Federal, Ministério do Trabalho e Emprego - dados compilados e tabulados pelos autores.

Percebe-se que além dos grupos imigratórios tradicionais - portugueses, italianos, alemães, espanhóis, japoneses e poloneses -, que já faziam parte do melting pot sul-rio-grandense (DACANAL, 1980), somam-se os imigrantes dos países fronteiriços, Argentina e Uruguai, e dos mais distantes geograficamente, Chile e Estados Unidos, dada a presença de empresas de capital estadunidense em território sul-rio-grandense.

É importante observar que o perfil imigratório não sofreu alterações desde os estudos já realizados por Becker (1958) 50 anos antes e também que não se

5 Os dados de população do estado do Rio Grande do Sul foram obtidos e consultados no "Atlas Socioeconômico do Rio Grande do Sul": < http:/ / www.atlassocioeconomico.rs.gov.br/conteudo. asp?cod_menu_filho=806\&cod_menu $=805 \&$ tipo_menu $=$ POPULA\&cod_conteudo $=1386>$. 
caracteriza por brasileiros com dupla-cidadania retornados, o que a literatura de imigração confunde algumas vezes ${ }^{6}$.

A representação cartográfica a seguir (FIGURA 2) traduz as estatísticas de imigração para o Rio Grande do Sul no ano 2000 e revela outras pontualidades que merecem destaque.

Figura 2 - Mapa de nacionalidade dos imigrantes no Rio Grande do Sul no ano 2000

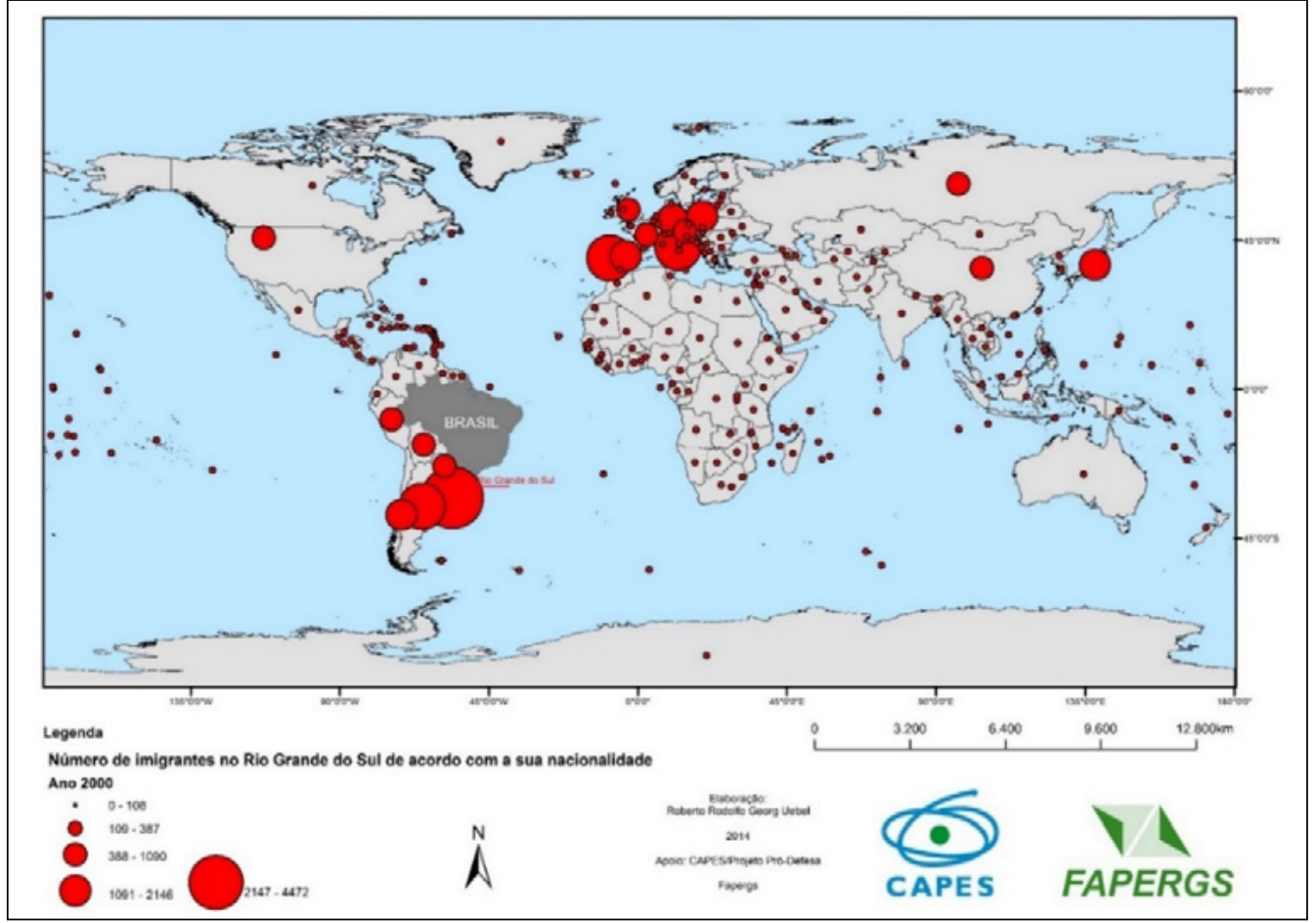

Fonte: elaborado pelos autores.

Optou-se por dividir a nacionalidade dos imigrantes em cinco classes nesse mapa: $1^{a}$ ) grupos inexpressivos; $2^{\mathrm{a}}$ ) grupos pequenos; $3^{\mathrm{a}}$ ) grupos médios; $4^{\mathrm{a}}$ ) grupos grandes; $5^{a}$ ) supergrupos.

A cartografia traz, portanto, que os fluxos imigratórios realmente seguiam um padrão tradicional sem alteração, em que predominavam em 2000 apenas grupos médios e grandes, de até 2.146 imigrantes, motivados predominantemente

6 Em muitas pesquisas observou-se que um expressivo aumento de imigração de determinada nacionalidade pode representar brasileiros que emigraram e estão em processo de retorno, após adquirirem dupla cidadania ou naturalizarem-se em outro país. Porém, os dados utilizados por esta pesquisa restringem-se apenas aos imigrantes natos e com autorizações de trabalho para estrangeiros, portanto, não teria como inserirem-se nas estatísticas brasileiros retornados. 
por: relações históricas e familiares com o Estado, presença de multinacionais estrangeiras em território sul-rio-grandense, motivações econômicas para a atuação no comércio informal e serviços, além dos grupos de refugiados, já que na época o Rio Grande do Sul participava do acolhimento de refugiados de guerra e perseguidos políticos, sendo o principal Estado brasileiro nessa ação humanitária.

No caso dos movimentos migratórios dos países do Mercado Comum do Sul (Mercosul) para o Rio Grande do Sul, pôde-se constatar a importância crescente dos movimentos intrabloco, não tanto por seu volume, mas por sua diversidade e suas implicações. A reestruturação produtiva e o contexto internacional produziram efeitos nessa área, no sentido de impulsionar novas modalidades de transferências populacionais.

Percebe-se, então, que esse novo cenário influenciou a transferência populacional tanto para as metrópoles como para outras cidades, cuja posição geográfica e competitividade atraíam indústrias novas e internacionais, iniciando um processo de transformação urbana já típica da etapa da própria economia sulrio-grandense.

Em contrapartida, a questão das fronteiras e das áreas limítrofes entre os países apresenta outra faceta das mudanças nesses movimentos. Em primeiro lugar, é possível que, em termos quantitativos, não tenha acorrido aumento expressivo dos movimentos migratórios em consequência dos acordos comerciais, se por migração estivermos entendendo a transferência de residência fixa. Contudo, novas formas de mobilidade espacial da população passaram a coexistir, incitando, inclusive, uma redefinição dos fenômenos emergentes que analisaremos para uma década posterior na próxima seção.

\section{Perfil imigratório do Rio Grande do Sul no ano 2010: o Estado frente ao Brasil na atraçáo dos migrantes internacionais}

Assim como ocorreu no perfil imigratório brasileiro - analisado na seção anterior -, o Rio Grande do Sul viu seu estoque de imigrantes duplicar em uma década, entre 2000 e 2010, passando de 17,5 mil imigrantes para 34,9 mil, respectivamente.

Ainda que seja um número representando apenas $8,1 \%$ da população de imigrantes em todo o território brasileiro, o estoque contabilizado no Rio Grande do Sul verificou aumento considerável de uruguaios - antes representando $26 \%$ e em 2010 já representando 47\% dos imigrantes no Estado - e também de novos grupos imigratórios, como paraguaios e chineses, no ranking dos dez maiores fluxos, conforme pode ser visualizado no Gráfico 5. 
Gráfico 5 - Representação percentual dos dez maiores grupos imigratórios no Rio Grande do Sul no ano 2010

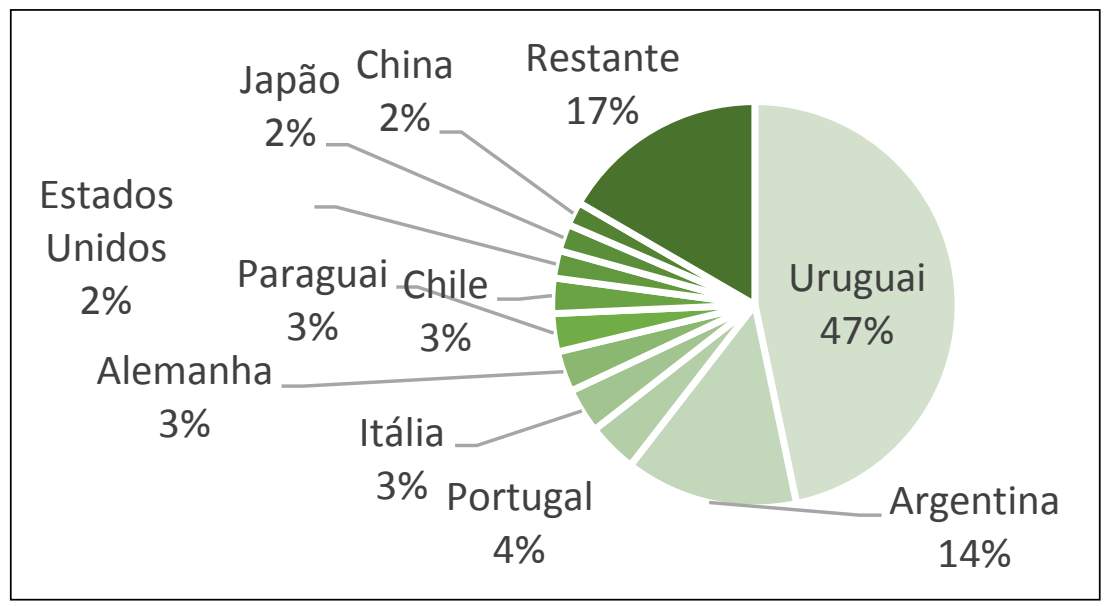

Fonte: Instituto Brasileiro de Geografia e Estatística, Departamento de Polícia Federal, Ministério do Trabalho e Emprego - sados compilados e tabulados pelos autores.

O que explica esse aumento do número de uruguaios e chineses em território sul-rio-grandense está centrado na atratividade econômica do Estado - que percebeu crescimento econômico acima da média brasileira no período - e na inserção de empresas chinesas no Rio Grande do Sul, que, além de contratar mão de obra local, trouxeram em grandes cifras chineses de formação média ou superior para os cargos mais qualificados.

Desde os anos 1970, os principais motivos da emigração dos uruguaios foram o desemprego e a queda do salário real, que frustraram as expectativas de mobilidade social. A violência política instalada pela ditadura militar do início dos anos 1970 e o processo de desindustrialização promoveram a emigração de muitos uruguaios de alta e média qualificação, muitos dos quais se tornaram emigrantes permanentes.

A emigração no final da década de 1990 foi uma resposta à crise econômica do período, visível nas elevadas taxas de desemprego e da inflação no Uruguai. A Argentina e o Brasil foram, até 2010, os principais destinos dos uruguaios que emigravam, embora nas últimas três décadas do século esses destinos se diversificaram, incluindo, entre outros países, os Estados Unidos, Austrália e Espanha.

Produziu-se reorientação, mormente da emigração que antes se orientava para a Argentina, devido ao aumento do desemprego e à queda do salário real nesse país e nos outros destinos citados acima, que convergiram e realocaram-se em direção ao Brasil e désormais ao Rio Grande do Sul, conforme pode ser observano na Figura 3. 
A emigração, para muitos uruguaios, faz parte das estratégias de vida (PELLEGRINO, 2000). O Uruguai, desde décadas atrás, mostra um padrão de emigração sustentado, que tem causado perdas de população significativas. A perda, por meio da emigração anual, estimada em 20.000 pessoas, em uma população de aproximadamente 3,3 milhões, supera o crescimento vegetativo da população do país (SALA; CARVALHO, 2008).

A emigração uruguaia, como aquela originária da Argentina, caracterizase pela composição predominantemente familiar e pela seletividade positiva, em termos educacionais, e pela inserção em empregos com requerimentos educacionais menores nos países de destino. Isso justificaria a escolha do Rio Grande do Sul como principal local de acolhimento, dadas as suas semelhanças com o Uruguai e a proximidade geográfica, um caráter facilitador no ato de emigrar e remigrar observado por muitos imigrantes econômicos (PIORE, 1979).

O mapa da Figura 3 mostra ainda as demais procedências dos imigrantes no ano de 2010 - o ano que consideraremos, além do seu boom imigratório, um divisor de águas das migrações internacionais para o Brasil e o Rio Grande do Sul, que insere o país e o Estado na agenda de destino final das imigrações contemporâneas.

Figura 3 - Mapa de nacionalidade dos imigrantes no Rio Grande do Sul no ano 2010

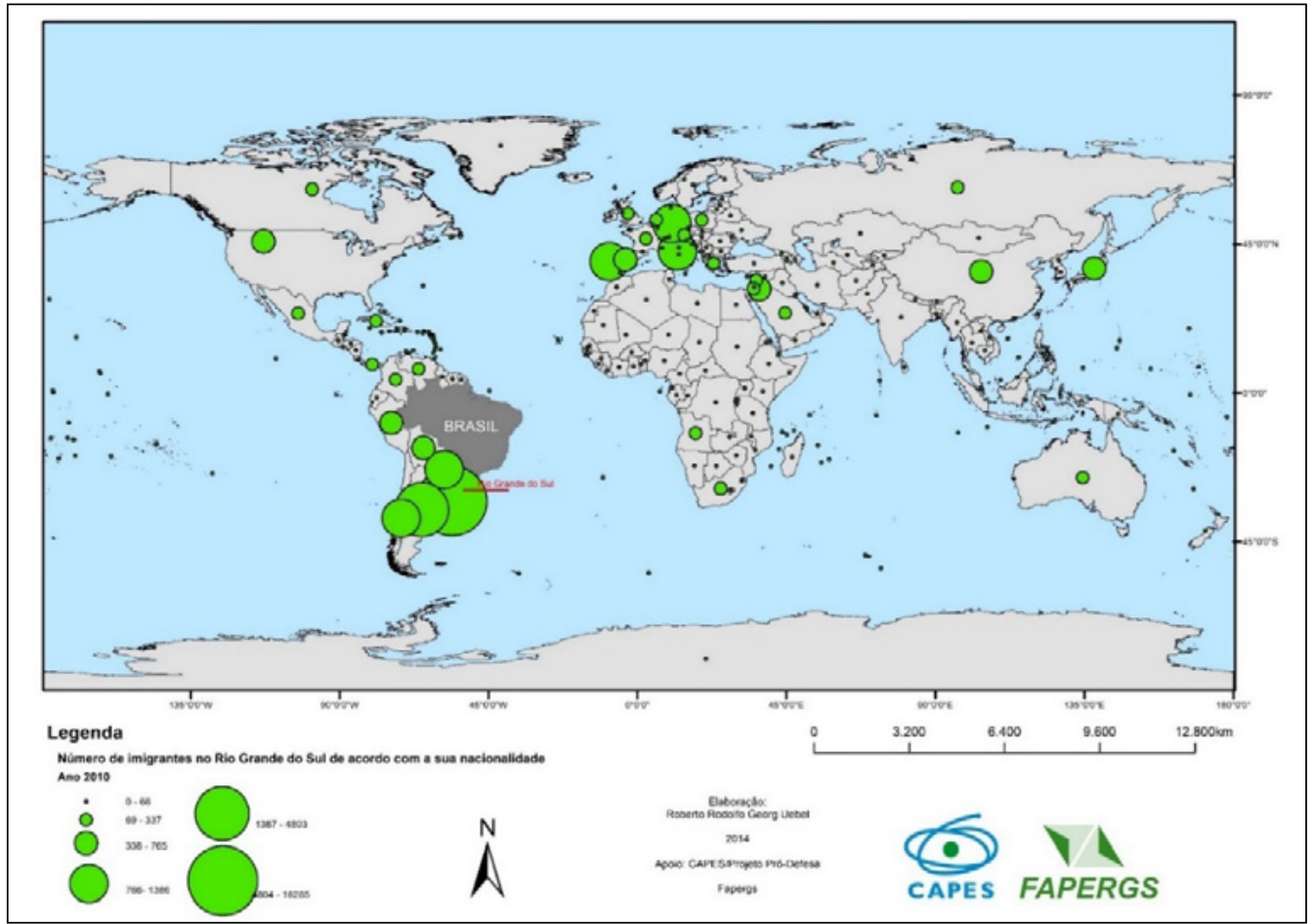

Fonte: elaborado pelos autores. 
Tem-se com Figura 3 a percepção de que o Estado passaria a incorporar nos anos seguintes novos fluxos e números maiores de imigrantes, já destacando aqueles de nacionalidade haitiana, angolanos, sul-africanos, palestinos, sauditas e gregos, além do próprio incremento dos nacionais de países que sofreram com a crise econômica internacional, em especial os portugueses, italianos e norteamericanos.

No período que compreendeu os anos de 2000 a 2010, além do Rio Grande do Sul e do mundo terem passado por expressivas transformações sociais, políticas e econômicas, o próprio caráter das migrações internacionais sofreu mudanças consideráveis: a maioria dos imigrantes registrados no Estado e no Brasil, segundo os dados da Polícia Federal, possuía curso superior e formação profissional registrada nos seus países de origem, diferentemente do registrado nos grupos imigratórios que chegaram no mesmo período na União Europeia - em especial na França e Alemanha - e de mesma origem.

A indagação que se apresenta, portanto, é que tanto o Rio Grande do Sul (em maior escala que o país) como o Brasil receberiam os imigrantes de melhor qualificação profissional e formação educacional do que os tradicionais receptores, como União Europeia, Estados Unidos, Austrália e Nova Zelândia.

Analisando-se o Gráfico $6 \mathrm{com}$ a linha de tendência de crescimento dos fluxos imigratórios para o Rio Grande do Sul, percebe-se que o ano de 2010 e posteriormente o biênio 2013-2014 seguem e, portanto, corroboram, o boom imigratório brasileiro.

Gráfico 6 - Linha de tendência dos fluxos imigratórios com direção ao Rio Grande do Sul no século XXI

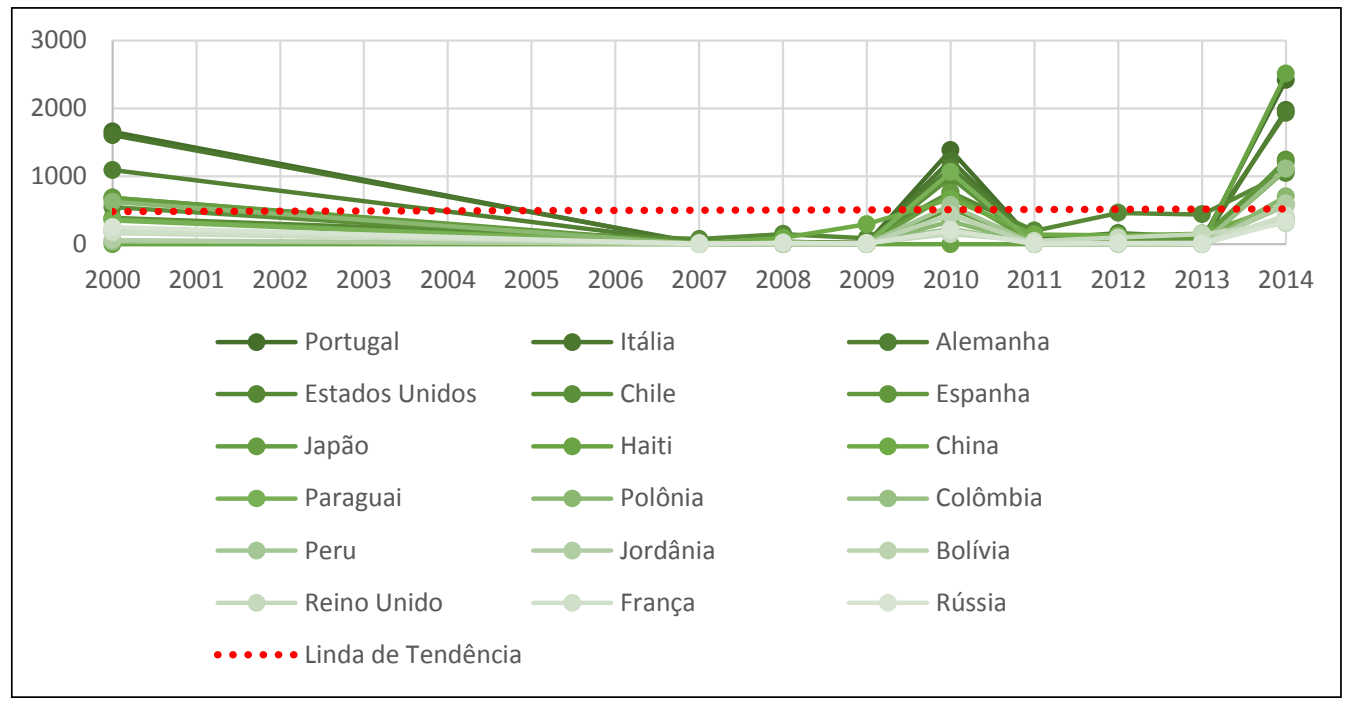

Fonte: Instituto Brasileiro de Geografia e Estatística, Departamento de Polícia Federal, Ministério do Trabalho e Emprego - dados compilados e tabulados pelos autores. 
Verifica-se um padrão de estabilidade dos fluxos imigratórios, que no Gráfico 6 apresenta o processo evolutivo de 18 deles (excluindo-se argentinos e uruguaios, a fim de destacarmos os demais grupos). Esse padrão não foi seguido pelos grupos imigratórios não tradicionais ou retomados, como no caso dos haitianos.

Nesse sentido, pode-se observar que já a partir de 2008, ano da crise econômica internacional, os fluxos apontavam para um aumento até o boom de 2010, com declínio mas com estabilização até 2013, quando houve novo boom.

Novamente a geografia da população permite a inferência dos dados quantitativos com base no cenário demográfico e geopolítico internacional, favorecendo a inserção do Rio Grande do Sul, frente ao Brasil, nas rotas imigratórias de grupos não tradicionais, como haitianos e senegaleses, que trataremos na análise do biênio 2013-2014 na próxima seção.

\section{Perfil imigratório do Rio Grande do Sul no biênio 2013-2014: novos fluxos e a retomada de migraçóes tradicionais - o Estado das imigraçóes}

Consoante observado-se nas seções anteriores, infere-se que o Estado do Rio Grande do Sul vem passando por um processo de transformação no seu perfil imigratório, caracterizado pelo aumento quantitativo dos fluxos - para aproximadamente $90 \%$ das nacionalidades -, e uma diferenciação dos tipos imigratórios, isto é, novas nacionalidades decidem imigrar para o Estado.

Os estrangeiros estão presentes no mercado de trabalho formal distribuídos pela vasta extensão territorial do Brasil. Entre 2011 e 2013, houve aumento da presença estrangeira em todas as Unidades da Federação, segundo Cavalcanti et al. (2014).

Existe uma considerável concentração nos Estados que compõem as regiões Sudeste e Sul. No triênio analisado, São Paulo se afirma como o Estado com o maior número de estrangeiros formalmente empregados. Dos 79.578 estrangeiros empregados no país em 2011, o mercado de trabalho paulista acolhia 27.515, ou seja, 34,6\% do total. Em 2013, São Paulo seguia como a unidade federativa (UF) que mais empregava estrangeiros, com 38.293 indivíduos. A participação percentual de São Paulo no agregado nacional, contudo, reduziu de 34,6\% em 2011 para 31,9\% em 2013.

Os Estados que experimentaram maior crescimento relativo foram Santa Catarina, com 63,5\% de 2011 para 2012 e 133,4\% de 2012 para 2013; Rio Grande do Sul, com 53,6\% de 2011 para 2012 e 42,0\% de 2012 para 2013; e Paraná, com crescimento de 44,2\% de 2011 para 2012 e 68,2\% de 2012 para 2013.

Esse crescimento do número de imigrantes no mercado de trabalho sul-riograndense segue a mesma tendência do crescimento do número geral de imigrantes no período de 2010 a 2014, de 124,9\%, e entre 2013 e 2014, com crescimento de $116 \%$. Esse crescimento é seguido pela nova composição imigratória do Estado, registrada na Figura 4. 
Figura 4 - Mapa de nacionalidade dos imigrantes no Rio Grande do Sul no ano de 2014

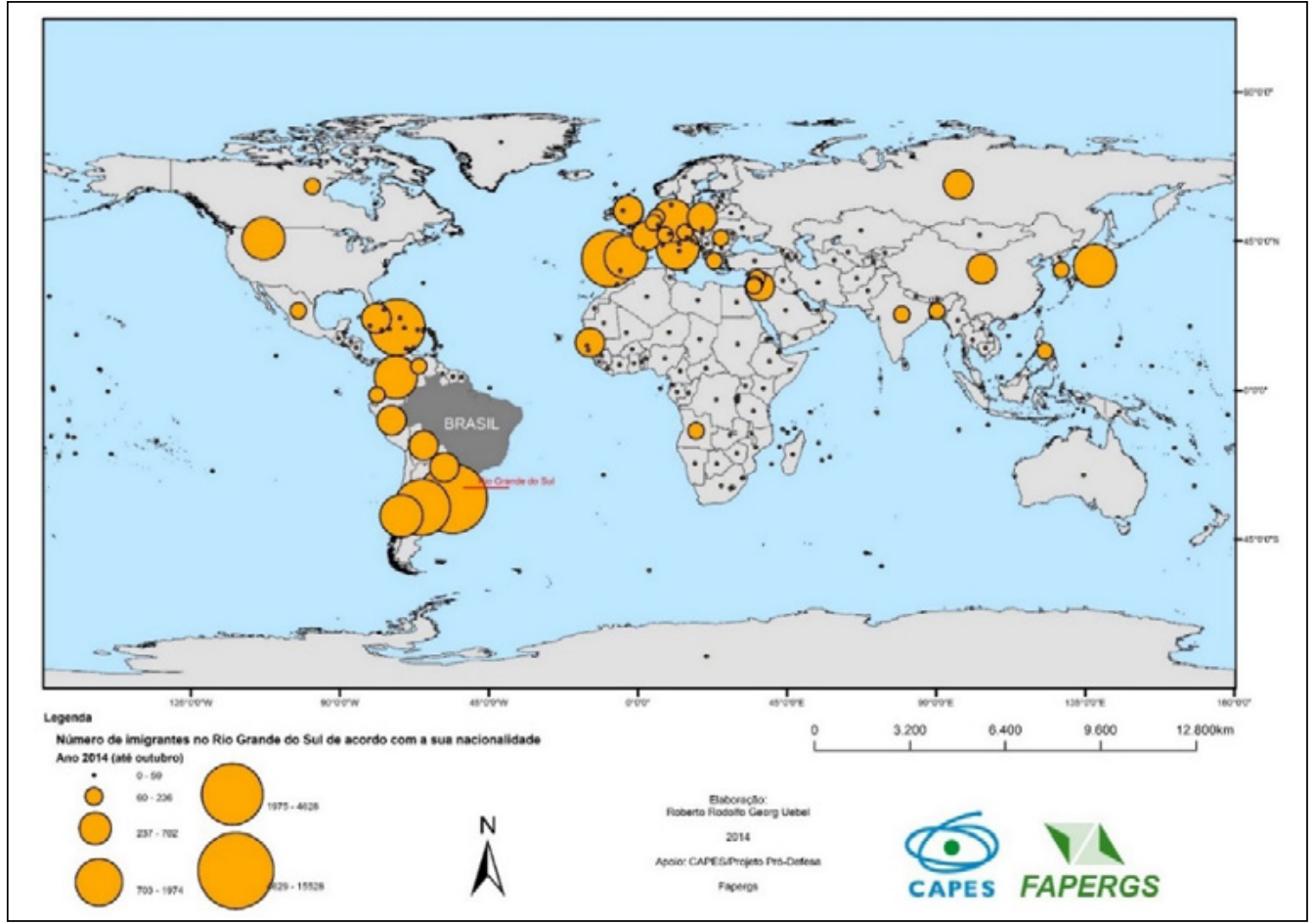

Fonte: elaborado pelos autores.

No mapa da Figura 4 é possível notar já o fenômeno das migrações dos haitianos e senegaleses, além da forte presença de imigrantes de nacionalidades portuguesa, espanhola e japonesa e de bengaleses, outro grupo com considerável participação no estoque imigratório do Rio Grande do Sul dos últimos anos. Esse mapa, se comparado com o mapa da Figura 3, permite visualizar também a evolução estatística dos quadros e fluxos imigratórios em direção ao Estado.

A interpretação que se apresenta de os haitianos ocuparem $6 \%$ e a terceira posição no ranking, antes ocupada por Portugal, é a inserção deles a partir de 2010 em território brasileiro e a consolidação dele fluxo imigratório, não podendo, portanto, ser considerado um fluxo temporário. Percebe-se também que os senegaleses, jordanianos e cubanos passam a ocupar representação considerável no perfil imigratório do Rio Grande do Sul no período em análise, apesar de possuírem motivações distintas que serão analisadas nos compounds regionais a seguir.

Antes de partirmos para a análise geocartográfica por continente dos fluxos imigratórios em direção ao Rio Grande do Sul, é importante fazer-se a seguinte comparação: em 2000 apenas 71 nacionalidades de imigrantes eram verificadas no Rio Grande do Sul, em 2010 eram 82 e em 2014 foram verificados 134 grupos imigratórios distintos, num universo de 200 nacionalidades observadas e catalogadas. Isso registra e ressalta novamente o papel de inserção do Estado nas redes e na agenda internacional das migrações. 
Nos mapas a seguir, destacam-se continente quais as nacionalidades que mais possuem imigrantes no Rio Grande do Sul, a fim de que possamos embasar esta pesquisa no próximo - e último - capítulo, acerca da inserção dos haitianos e senegaleses no Estado.

O mapa da Figura 5 apresenta a quantificação do número de imigrantes provenientes do continente americano com destino ao Rio Grande do Sul entre 2013 e 2014.

Figura 5-Mapa de nacionalidade dos imigrantes no Rio Grande do Sul provenientes do continente americano e do Caribe

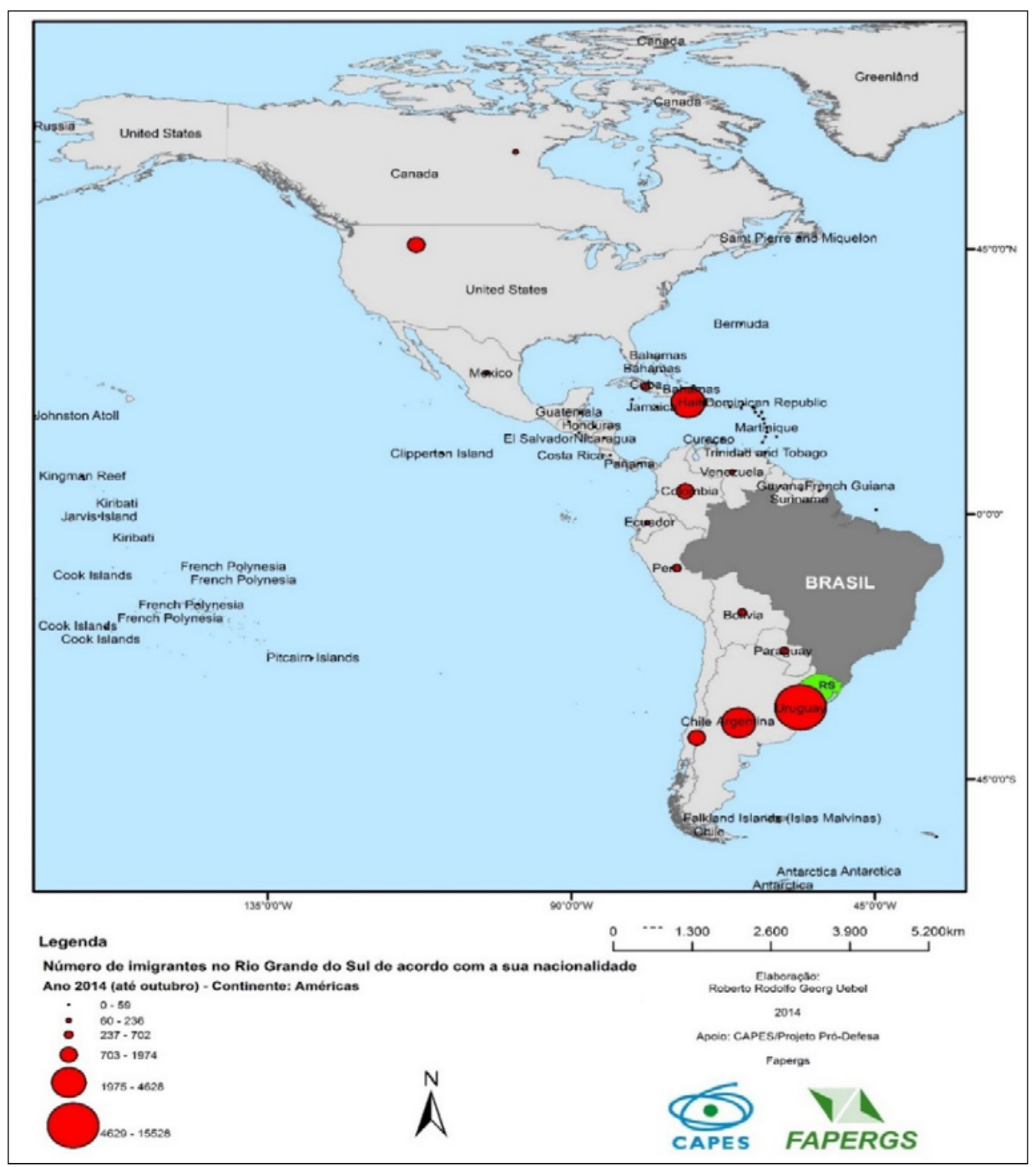

Fonte: elaborado pelos autores. 
Ao contrário do cenário brasileiro para o mesmo período, analisase que no Estado do Rio Grande do Sul, apesar da participação estatística e numérica, proporcionalmente os vizinhos Paraguai, Bolívia e Chile estão em menor representação, ao passo que os imigrantes de origem uruguaia, argentina, colombiana e haitiana, além dos estadunidenses, possuem grande participação no estoque imigratório de 2013 a 2014.

O número de uruguaios e argentinos no Rio Grande do Sul, conforme mencionado anteriormente, tem a sua expressividade justificada por um conjunto de fatores: atratividade econômica do Estado, proximidade geográfica, similaridade cultural e a própria presença de loci imigratórios dessas nacionalidades.

A imigração fronteiriça apresenta singularidades em relação às imigrações internacionais de longa distância e às migrações em contextos nacionais. Em sentido amplo, os processos migratórios são deslocamentos fronteiriços, pois os contatos com outras realidades sociais criam barreiras e produzem travessias e fluxos culturais.

De maneira mais específica, entretanto, compreende-se a imigração fronteiriça como os deslocamentos populacionais nas zonas de fronteira entre países vizinhos. Os imigrantes fronteiriços, com exceção das ocasiões de guerra ou outros conflitos diplomáticos entre a nação de origem e a de destino, continuam mantendo muitos contatos com seu país e permanecem se comunicando em seu idioma nativo. Além disso, os sinais dos canais de televisão e das ondas dos rádios dos países limítrofes alcançam essas zonas de fronteira e ampliam os raios das "imaginações nacionais", por exemplo (ALBUQUERQUE, 2008).

Esse processo de enquistamento (NOVAES, 2013), todavia, não ocorre como uma justificativa para as migrações de colombianos e haitianos, por exemplo, já que eles se mostram instalados por todo o território do Rio Grande do Sul, apesar de alguns conviverem em comunidades de não mais de duas dezenas de pessoas.

O que justifica a presença considerável de colombianos no Rio Grande do Sul são as redes migratórias internacionais na seara do refúgio e asilo político. Nesse sentido, a rede que começa na Colômbia possui como estado transitório o Equador e destino final o Rio Grande do Sul, conforme descrito a seguir:

33 colombianos chegaram ao Estado. Eles tiveram refúgio aceito pelo governo brasileiro, após sofrerem ameaças no país natal. Alguns, inclusive, pelas Forças Armadas Revolucionárias da Colômbia, segundo o Ministério da Justiça do Brasil. Outros 25 colombianos irão para São Paulo. O coordenador geral de assuntos para refugiados do Ministério da Justiça, Virginius Lianza, explica que os imigrantes ficarão em diferentes cidades gaúchas. As famílias estão no Equador, mas pediram a vinda ao Brasil às Nações Unidas por não se adaptarem ao país. O colombiano Isac, que prefere ser identificado apenas pelo primeiro nome, vive no Rio Grande do Sul há quatro anos com a mulher e três filhos. [...] Hoje, mais de 300 colombianos estão reassentados no país, e cerca de 150 aqui no Estado (BRUNO, 2013). 
Assim, o que caracteriza esse aumento e a presença expressiva de colombianos no território sul-rio-grandense está majoritariamente ligado ao status de refúgio obtido por eles, não sendo caracterizados, portanto, como imigrantes econômicos.

Já os haitianos são predominantemente motivados pela atratividade laboral e econômica do Estado, coincidente com o aumento do número de vagas registrado pela indústria e comércio rio-grandense no mesmo período e pela inserção estratégica do Brasil no Haiti.

Por fim, os imigrantes de nacionalidades boliviana e paraguaia não possuem representatividade considerável no cenário imigratório do Rio Grande do Sul em virtude de que eles preferem imigrar para os Estados fronteiriços aos seus países, como Mato Grosso, Mato Grosso do Sul e São Paulo, conforme exposto na pesquisa de Ranincheski e Uebel (2014), e pelo fator já considerado de que os imigrantes de nacionalidades vizinhas são predominantemente fronteiriços em suas localidades de residência, isto é, cada Estado brasileiro tem nas suas principais composições (e rankings) imigrantes de países vizinhos: uruguaios e argentinos no Rio Grande do Sul, bolivianos e paraguaios no Mato Grosso, peruanos e bolivianos no Acre etc.

Já a participação dos imigrantes de origem europeia no cenário do Estado no biênio de 2013-2014 segue em certa medida o padrão da escala brasileira, mas apresenta algumas peculiaridades, que podem ser observadas na Figura 6. 
Figura 6 - Mapa de nacionalidade dos imigrantes no Rio Grande do Sul provenientes da Europa

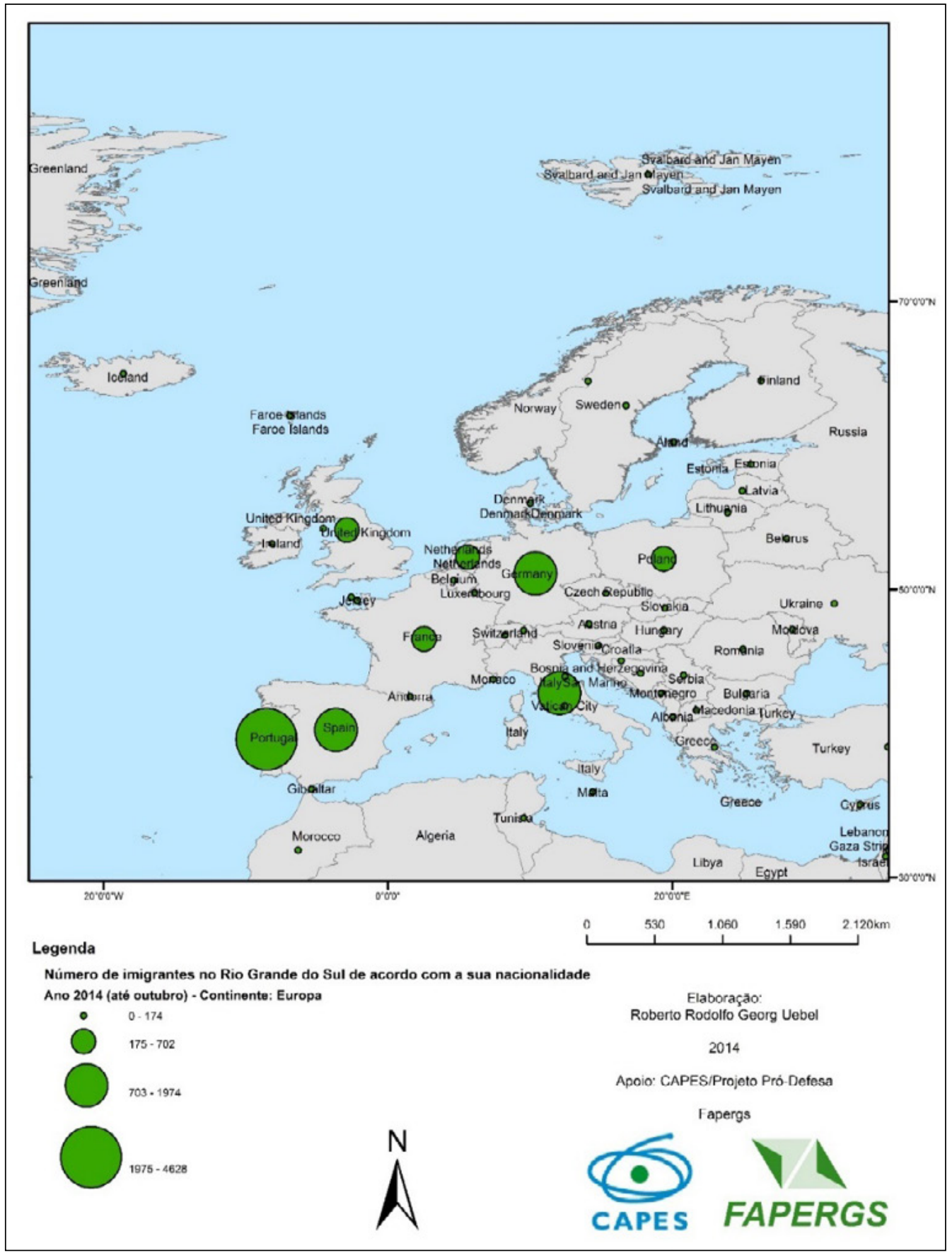

Fonte: elaborado pelos autores. 
Seguindo o padrão brasileiro, os imigrantes de origem portuguesa, espanhola e italiana ainda possuem forte representação na composição do perfil imigratório do Rio Grande do Sul nos últimos anos em função da forte crise econômica lá registrada, ao contrário dos estadunidenses, por exemplo, que retornaram aos Estados Unidos dada a recuperação econômica e dos postos de trabalho no país.

Ademais, verifica-se no Rio Grande do Sul a presença de imigrantes alemães, poloneses e holandeses em proporção maior que a verificada no restante do Brasil, já que o Estado possui uma histórica e consolidada rede e/imigratória para com a Alemanha (DREHER, 2014), Polônia (GLUCHOWSKI, 2005) e Países BaixosHolanda (WITTE, 1991).

Essas redes mostram-se efetivas e mantidas ao longo das últimas décadas, prevalecendo-se a hipótese de que as redes migratórias são o principal aporte e esteio das migrações internacionais e que são fundamentais no processo de tomada de decisão de emigrar por parte do indivíduo imigrante (ROCHA-TRINDADE, 1995).

Assim sendo, pode-se inferir que a recente alteração nos fluxos migratórios de europeus e o consequente interesse pelo Brasil e pelo Rio Grande do Sul como destinos da imigração seriam resultado não somente de fatores estruturais, como o crescimento econômico do país e de melhor inserção internacional, mas também de fatores subjetivos, qual seja: a leitura que os agentes migratórios fazem da imagem do país e do Estado no cenário internacional. Além disso, o desenvolvimento dos laços sociais entre os países de origem e de destino faz com que o fluxo migratório se torne cada vez mais estruturado (PAIVA; LEITE, 2014).

Outrossim, os grupos imigratórios que mais vêm chamando atenção no perfil imigratório do Rio Grande do Sul nos últimos anos, além dos haitianos, são aqueles originários do continente africano, assim como os refugiados e asilados do Oriente Médio.

O mapa da Figura 7 apresenta os países de origem com maior frequência de imigrantes com direção ao Rio Grande do Sul provenientes da África e do Oriente Médio no período de 2013 a 2014. 
Figura 7 - Mapa de nacionalidade dos imigrantes no Rio Grande do Sul provenientes da África e Oriente Médio

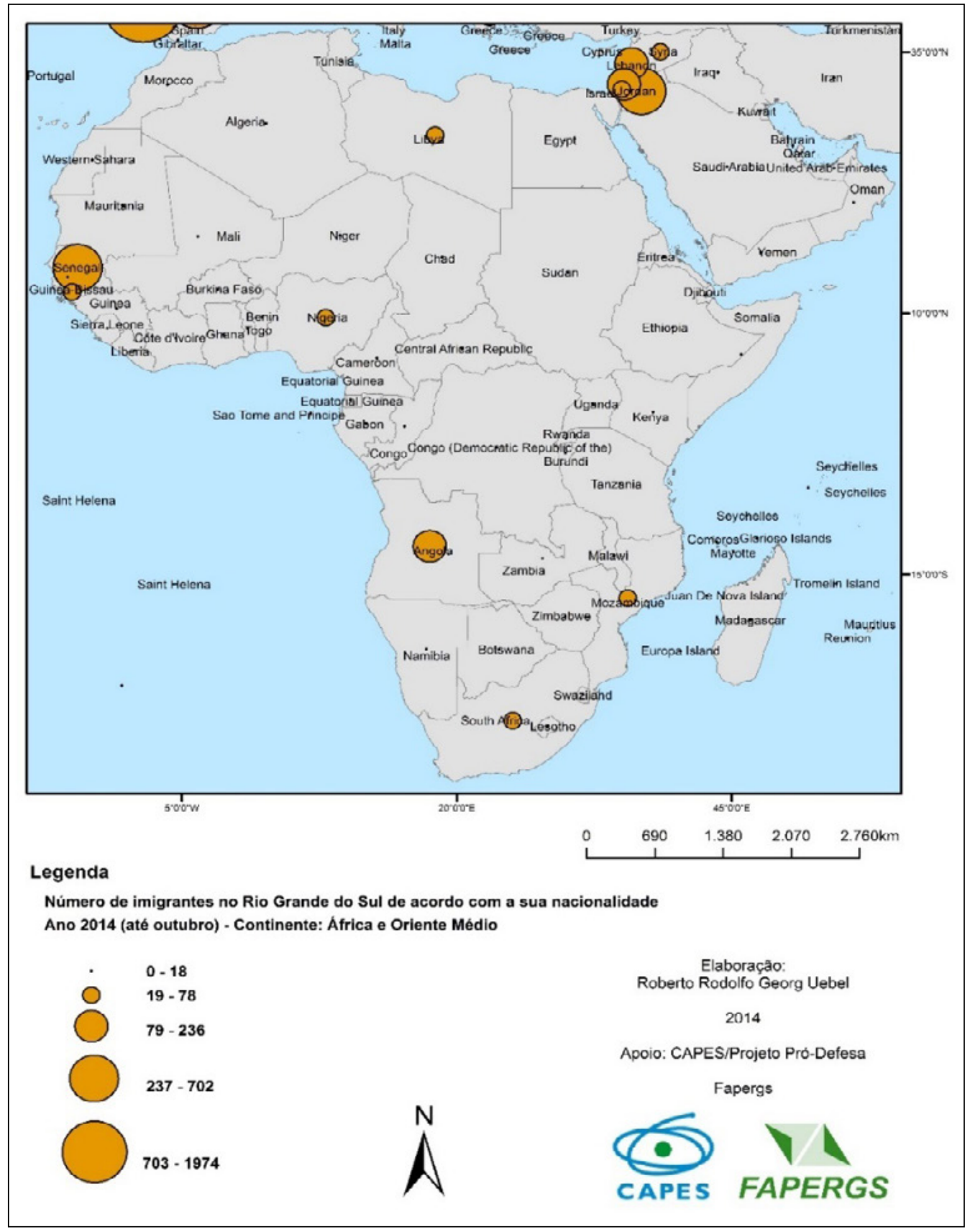

Fonte: elaborado pelo autor. 
Observa-se que os grupos imigratórios mais expressivos provenientes da África se localizam especialmente na Costa Oeste, à exceção da África do Sul e Moçambique. Senegaleses, guineenses, nigerianos e angolanos destacam-se pelo incremento ao estoque imigratório do Rio Grande do Sul.

Outro destaque importante que provém do continente africano é o caso dos imigrantes ganeses, que foram destacados pela imprensa - até mesmo negativamente, usando-se termos como "invasão", "fugidos", "pobres" - no primeiro semestre de 2014, conforme relatado a seguir:

A situação dos ganeses em Caxias do Sul, na Serra do Rio Grande do Sul, está chegando a um ponto crítico. [...] mais 55 cidadãos de Gana chegaram à cidade do Rio Grande do Sul para encaminhar pedidos de refúgio e legalizar a permanência no Brasil. Os ganeses entraram no país com vistos de turistas, concedidos pela embaixada brasileira em Acra, capital do país. De acordo com o Centro de Atendimento ao Migrante (CAM), entidade que recebe e atende os estrangeiros recém-chegados, em 13 dias, 327 ganeses já passaram pela cidade. Segundo as autoridades, promessas de emprego, facilidades para conseguir o protocolo de refugiado e uma rede de assistência aos imigrantes são os principais atrativos de Caxias do Sul para os ganeses que desembarcam em busca de uma nova vida no Brasil. A rapidez na emissão do protocolo de refúgio na cidade da Serra estava atraindo imigrantes de vários Estados do país, como Santa Catarina, São Paulo e Minas Gerais (CANOFRE, 2014).

A questão que perdurou por aproximadamente três meses no Estado do Rio Grande do Sul em relação aos ganeses deu-se por sua permanência - em números consideráveis - na Serra gaúcha, dada apenas e exclusivamente pela rapidez na emissão dos documentos de refugiados. Portanto, entendemos que esses migrantes são refugiados, migrantes internos do Brasil e não imigrantes econômicos.

Essa hipótese está corroborada pelo fato de que, segundo dados da Polícia Federal, apenas 14 ganeses possuíam residência no Estado do Rio Grande do Sul em novembro de 2014, tendo os demais cidadãos migrado para outros Estados brasileiros, como Santa Catarina, ou para outros países, como o Equador, país tradicionalmente receptor de refugiados na América do Sul.

Desse modo, o mapa da Figura 7 sequer elucida a participação proporcional dos ganeses no estoque imigratório do Rio Grande do Sul, não sendo um grupo de expressão nessa composição, apesar de todo o esforço que a mídia fez para transformá-los em uma "ameaça" ao mercado de trabalho e à população sul-riograndense.

Ademais, o caso dos angolanos, nigerianos e sul-africanos está pautado por uma situação distinta da dos imigrantes da costa oeste africana ou dos refugiados e migrantes internos ganeses, já que possuem perfil social, laboral e econômico distinto. Se analisadas as estatísticas da Polícia Federal, pode-se inferir que essas três nacionalidades de imigrantes estão inseridas no contexto de: intercambistas em centros de ensino superior do Rio Grande do Sul, missionários de igrejas e, em menor parte, trabalhadores da construção civil e do setor naval, porém, todos já emigraram para o Rio Grande do Sul com uma proposta de emprego ou atuação 
profissional consolidadas, caracterizando-se uma imigração específica, demandada e, em alguns casos, temporária.

Esse tipo de imigração é recorrente em províncias do Canadá, por exemplo, que recebem o mesmo perfil de imigrantes. Por exemplo, poderia se criar uma correlação entre os imigrantes africanos na província do Québec com as três nacionalidades citadas no Estado do Rio Grande do Sul. Ambos os grupos imigratórios possuem perfis semelhantes e propósitos e durabilidade similar.

Nesse sentido, a imigração de africanos para o Rio Grande do Sul coloca o Estado no rol de unidades federativas partícipes na agenda internacional de imigração, como Québec (Canadá) e Catalunha (Espanha), dentre outros (ANTECOL et al., 2004).

Se compararmos a origem dos imigrantes africanos para o Estado e para o Brasil, percebe-se que a hipótese do parágrafo anterior está correta, transformando o RS em uma unidade seletiva - seja objetiva ou subjetivamente - dos grupos imigratórios, dadas as condições laborais e econômicas do território gaúcho e o perfil dos próprios imigrantes, já que no Rio Grande do Sul sequer se observa a presença de congoleses, camaroneses, malianos, por exemplo, que possuem forte participação no estoque imigratório total do Brasil.

Já os imigrantes do Oriente Médio (predominantemente palestinos, jordanianos, libaneses e sírios, somando-se também os imigrantes líbios), são cidadãos em sua maioria com status de refúgio ou com imigração temporária para o Brasil, já que sabidamente há a existência de uma rota desses grupos imigratórios em direção ao Uruguai e ao Paraguai e a presença deles nas cidades fronteiriças.

Ou seja, há inúmeras "Pequenas Palestinas" nas cidades-gêmeas entre Brasil, Uruguai, Argentina e Paraguai que historicamente acolhem os imigrantes das nacionalidades árabes e muçulmanas. A ideia do melting-pot permite então compreender a existência destas comunidades imigratórias nas regiões transfronteiriças sem a perda de suas identidades ímpares.

Do ponto de vista geográfico, a participação desses grupos imigratórios está limitada, portanto, às cidades fronteiriças e em menor parte localizada nos centros urbanos, atuando, já sob a percepção econômica, em atividades do comércio, predominantemente.

O que se torna interessante nestes grupos imigratórios do Maxerreque ${ }^{7}$ é a transformação deles, em sua maioria refugiados, em imigrantes econômicos e, muitas vezes, a posteriori, cidadãos naturalizados brasileiros, tendo total integração com a sociedade local sem perderem seus costumes e tradições.

7 É um termo árabe que significa "levante" e designa a parte oriental do Mundo Árabe, complementar ao Magrebe ou "poente". É um conceito geográfico e cultural. Fazem parte do Maxerreque todos os países árabes situados a leste da Líbia, tradicionalmente considerada como território de transição, embora modernamente se inclua dentro do Magrebe e seja membro da União do Magrebe Árabe. 
A discussão feita por Cortes (2004) pondera que o processo de transformação do refugiado em imigrante econômico muitas vezes ocorre ainda durante a rota imigratória ou logo após a sua instalação no país de destino, e que se transforma numa evidência empírica heterogênea, isto é, uma amalgamação dentro da própria comunidade imigrante daqueles que são refugiados, imigrantes ou apátridas, notadamente observado no caso dos árabes e muçulmanos instalados no Rio Grande do Sul nas últimas décadas.

Os apátridas também merecem destaque na análise geocartográfica do mapa da Figura 7, em virtude de que, apesar de não possuírem nacionalidade, esse grupo de estrangeiros é predominantemente de origem do continente africano e da Península Arábica, por inúmeros motivos, mas, principalmente, em razão dos conflitos e instabilidade político-administrativa que não permite o registro desses cidadãos quando do seu nascimento.

Apesar de não serem em grande quantidade, os apátridas no Rio Grande do Sul representam 6,4\% do total verificado no Brasil, sendo um dos principais Estados que recebem essa categoria de estrangeiros após os Estados do Sudeste. Já os imigrantes de origem asiática representam outra importante participação no perfil e estoque imigratório sul-rio-grandense deste novo século, conforme observa-se na sua participação e procedência na Figura 8. 
Figura 8-Mapa de nacionalidade dos imigrantes no Rio Grande do Sul provenientes da Ásia

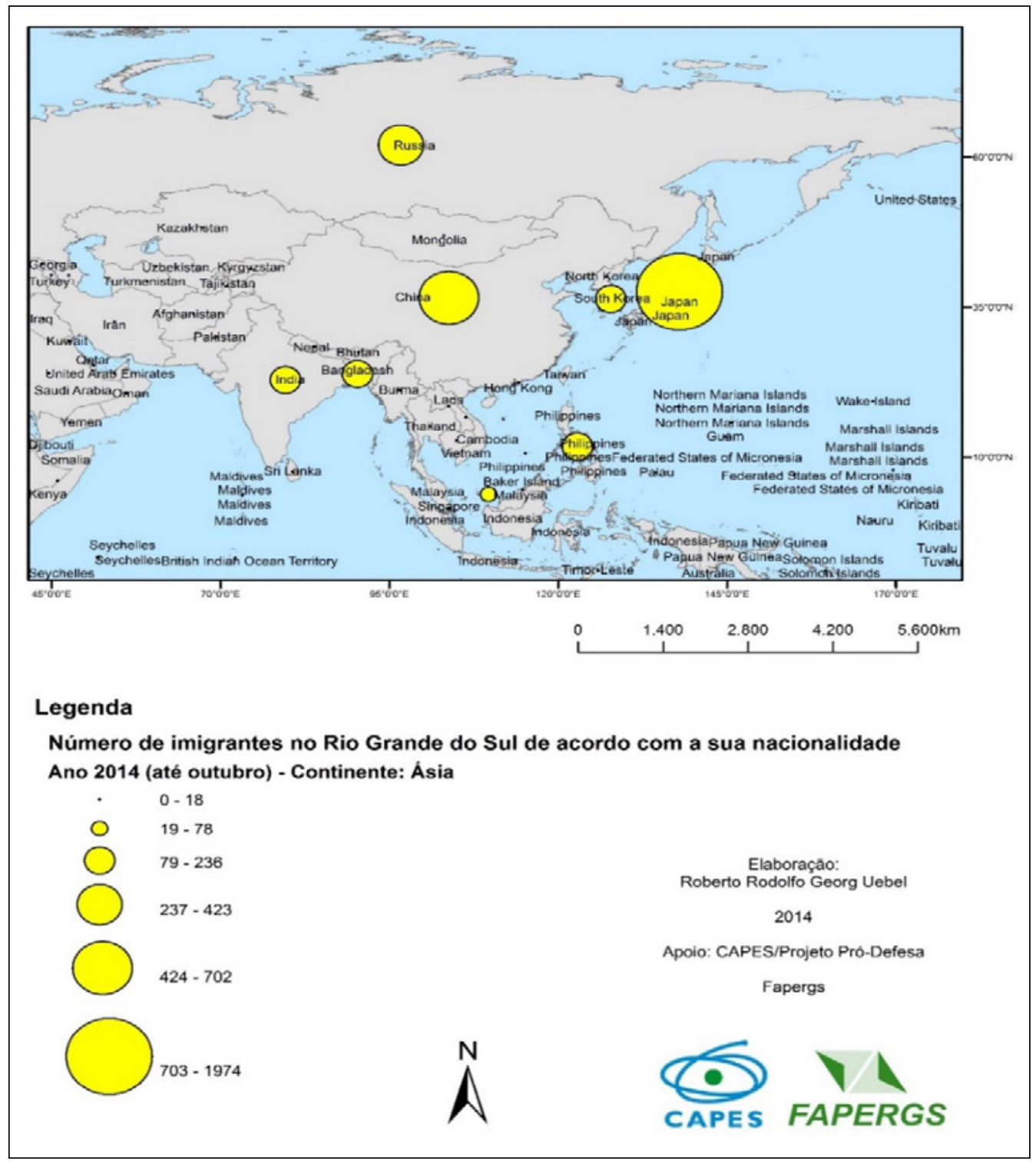

Fonte: elaborado pelos autores.

Estado destino da imigração japonesa no início do século XX (GAUDIOSO, 2008), o Rio Grande do Sul possui uma das maiores comunidades de imigrantes dessa nacionalidade, juntamente com São Paulo, Paraná, Bahia, Minas Gerais e Rio de Janeiro, ranking que não mudou desde o início dessa imigração em 1908. O fluxo de japoneses para o Brasil e, por conseguinte, para o Rio Grande do Sul sempre 
foi constante e oscilou em períodos de crise no Brasil e no Japão, não podendo ser considerado um fenômeno pontual, mas, sim, um fluxo constante e infindável.

Assim como os japoneses, a imigração de russos para o Estado não é recente e remonta ao período após o fim da Guerra da Crimeia, ainda no final do século XIX. A comunidade russa do Rio Grande do Sul ocupa uma posição bastante emblemática entre as comunidades russas do Brasil.

No Rio Grande do Sul, no Paraná e em Santa Catarina, o fluxo de imigrantes foi bastante alto, e diferentemente de São Paulo, algumas cidades dessas regiões tornaram-se núcleos de concentração dessas imigrações caracterizando a formação cultural dessas cidades.

As cidades de Santa Rosa, Santo Ângelo e principalmente Campina das Missões tornaram-se as principais em referência para a imigração russa no Rio Grande do Sul. Os registros de imigração russa para o Brasil são datados a partir de 1870. No Rio Grande do Sul, a imigração se inicia 1909, trazendo três ondas de imigração posteriormente:

A primeira onda de imigração russa ocorreu no início do século XX e compôs em sua maioria, imigrantes provenientes de áreas rurais, muitos especialistas nas áreas de plantio e trabalho da terra, agricultores, marceneiros e diversas outras formas de culturas e criação de animais. Na segunda onda de 1917, a imigração foi motivada em razão da revolução bolchevista, na composição dos imigrantes a maioria era técnicos, engenheiros, profissionais das artes, agrônomos, médicos entre outros, a maioria se estabeleceu no Rio Grande do Sul e em São Paulo. Já a terceira onda e principal em questão de volume, ocorreu por volta de 1945 durante os anos da segunda guerra mundial, onde o fluxo de imigrantes russo foi maior do que em períodos anteriores (MELO, 2010, p. 1).

O que se apresenta na contemporaneidade, portanto, é interpretado como uma quarta onda de imigração russa, voltada agora para postos de trabalho especializados e imigrantes acadêmicos, concentrados em polos como Porto Alegre, Santa Maria e Caxias do Sul, isto é, profissionais de universidades e estudantes de ensino superior em razão da cooperação de ensino firmada entre o Brasil e a Rússia sob a égide dos BRICS (Brasil, Rússia, Índia, China e África do Sul).

Aliando-se à presença dos russos e japoneses, a comunidade de imigrantes chineses e indianos no Rio Grande do Sul também é muito expressiva e segue a tendência da imigração russa: profissionais que atuam em empresas de tecnologia e automobilísticas, profissionais informais e do comércio (os populares camelôs) e intercambistas de ensino superior e de pós-graduação.

Dentro dessa questão, observamos que o Brasil possui diversos acordos de cooperação e atos bilaterais ${ }^{8}$ com Rússia, Índia, China, Coreia do Sul e Japão

8 Os atos internacionais foram consultados no Sistema de Atos Internacionais do Ministério das Relações Exteriores do Brasil e podem ser acessados pela página <http://dai-mre.serpro.gov.br/ pesquisa_ato_bil>. 
que justificariam e explicariam o aumento expressivo das imigrações provenientes desses países com destino ao Brasil e ao Rio Grande do Sul após o ano de 2010 e mais fortemente em 2013-2014, anos de instalação de empresas de capital originário daqueles países, assim como profissionais e estudantes, em território gaúcho.

Nesse sentido, infere-se que a imigração de japoneses, chineses, russos, indianos e sul-coreanos para o Rio Grande do Sul, somada à instalação de empresas de capital e administração dessas mesmas nacionalidades em território gaúcho, corresponderia e justificaria os aumentos de fluxos nos anos analisados, expressados no mapa da Figura 8.

Assim, acredita-se ser um novo conjunto partícipe do novo perfil imigratório do Rio Grande do Sul, referindo-se àquela parte de imigrações - subjetivamente - subvencionadas e incitadas por meio de acordos, conforme apresentado anteriormente. Essas nacionalidades são, então, resultantes e configuradoras dos processos imigratórios estimulados verificados no Estado após o ano de 2010 e com boom após 2013; um novo tipo configuracional das imigrações no Rio Grande do Sul.

Por fim, o continente asiático ainda apresenta três nacionalidades de imigrantes que caracterizam o novo perfil imigratório do Rio Grande do Sul, nesse sentido, semelhante ao verificado pelos senegaleses: bengaleses, malaios e filipinos.

Esses grupos representam mais de 50 imigrantes no território do Rio Grande do Sul e seguem as mesmas atividades laborais dos africanos e haitianos nos setores da indústria e comércio, ainda que sejam alguns ambulantes.

A diferença residual entre o grupo de asiáticos e o dos haitianos/africanos está na forma como chegam ao Estado e nas próprias rotas migratórias e redes de contato: ao passo que a maioria dos africanos e haitianos migram por meio de redes e utilizam-se de países intermediários (Peru e Bolívia para haitianos, Angola, Marrocos, África do Sul e Espanha para africanos), os asiáticos migram em navios cargueiros, vêm diretamente, sem um coiote ou intermediário, ou utilizam-se de linhas aéreas via Emirados Árabes ou Turquia e ingressam no Rio Grande do Sul pela fronteira com a Argentina, muitas vezes em situações precárias ou sem documentação.

Segundo dados do Comitê Nacional para os Refugiados (Conare), no ano passado, até novembro, 1.830 bengaleses entraram no Brasil e solicitaram status de refugiados - mais do que o dobro do total de cidadãos do segundo país com maior número de solicitações no mesmo período, Senegal (799).

Apesar de não terem o pedido de refúgio atendido - por não se encaixarem nos critérios do governo para isso -, os bengaleses, os malaios e os filipinos acabam permanecendo no país, recebendo direito a residência permanente. Sem isso, e sem o status de refugiados, eles poderiam ser deportados do país.

A chegada de imigrantes ou refugiados vindos de Bangladesh ou de nacionalidades que tradicionalmente não migravam em massa ao Brasil e ao Rio Grande do Sul, como Malásia e Filipinas, é, portanto, um fenômeno recente. 
Essa diversificação, segundo autoridades, é fruto da crescente projeção brasileira no exterior, aliada às crescentes restrições à entrada de imigrantes na Europa, nos Estados Unidos e Austrália, país que tradicionalmente recebe as nacionalidades asiáticas.

Assim, em relação aos bengaleses, malaios e filipinos, o Rio Grande do Sul apresenta-se como um absorvedor de estoques e fluxos imigratórios antes capitaneados por países como Austrália, Nova Zelândia e Cingapura, empregandoos nas mesmas atividades laborais que lá exerceriam, ou seja, muda-se o local de destino, mas a atividade de trabalho permanece a mesma para eles.

\section{Consideraçóes finais e perspectivas}

Ao longo deste artigo observou-se que, assim como ocorreu no Brasil, o Rio Grande do Sul percebeu uma mudança no seu perfil imigratório ao longo dos anos de 2000 a 2015, sustentado nas próprias mudanças do cenário econômico e do trabalho na esfera internacional, tornando-o mais atrativo que outros países ou territórios tradicionalmente receptores de imigrantes.

Além disso, verificou-se que o Estado, além de receber grupos imigratórios tradicionais de países fronteiriços, experimentou também a chegada de novos fluxos imigratórios, de refugiados, apátridas, asilados, assim como a retomada de imigrações tradicionais da Europa e da Ásia. O Estado caracterizou-se, também, como um território de migrações temporárias dentro do Brasil, em especial no caso dos imigrantes ganeses, que foram sumariamente expostos na mídia estadual e acabaram migrando para outros países ou outros estados do Brasil.

O Rio Grande do Sul vem apresentando então uma significativa alteração na sua configuração e estoque imigratório, despontando como principal Estado brasileiro a seguir a tendência de reformulação, dadas as suas características históricas, econômicas, sociais e geográficas.

Pode-se pensar que o Rio Grande do Sul é o motor propulsor à inserção estratégica do Brasil na agenda internacional das migrações, face os indicadores que aqui analisamos em conjunção com os documentos cartográficos, apesar de que os outros Estados brasileiros absorvam outros grupos migratórios em maior quantidade. Porém, se compararmos as estatísticas de outros Estados, conforme viu-se ao longo do artigo, verifica-se que o RS possui as mesmas características de imigração de unidades administrativas-chave como Québec e Catalunha, por exemplo.

Nesse sentido, o Estado do Rio Grande do Sul não só coloca o Brasil como um dos principais destinos das migrações internacionais, sejam econômicas ou de refúgio, mas também coloca o seu território nas principais rotas imigratórias internacionais que, em proporção, coaduna com aquelas verificadas na União Europeia, por exemplo.

Em relação ao futuro das imigrações para o Rio Grande do Sul, é necessário ter em consideração o próprio crescimento econômico dos países que mais enviam 
imigrantes para o Estado, assim como do Rio Grande do Sul e suas projeções futuras, além do Índice de Desenvolvimento Humano. Com a análise desses indicadores é possível perceber que o Estado do Rio Grande do Sul possuía atração tanto econômica quanto social superior a esses países até meados de 2015, o que justificaria para os próximos anos a continuidade dos fluxos imigratórios, em especial dos haitianos e senegaleses, por exemplo.

Com a crise econômica e laboral vislumbrada conjunturalmente no Brasil a partir do segundo semestre de 2015, essas tendências de redução da atividade econômica e de oferta de emprego, entretanto, deverão se refletir no perfil imigratório do Estado, apesar da chegada constante de novos imigrantes semanalmente. Acreditamos, desse modo, que para o médio prazo o Rio Grande do Sul observará redução dos seus influxos migratórios e declínio nas projeções da própria série histórica.

Apesar das projeções de declínio, em suma, o Rio Grande do Sul se caracteriza como uma das principais unidades federativas do Brasil na recepção de imigrantes e sua inserção no mercado de trabalho, oriundos das mais diversas partes do planeta. Ao mesmo tempo, assemelha-se a outras regiões de igual influência e intensidade imigratória, como o Québec e a Catalunha, ambos nos níveis regionais de seus respectivos países. Portanto, esse perfil imigratório prenuncia outras questões promissoras de cunho social e econômico ao desenvolvimento do Estado em si, além de desafios para a gestão dessas migrações para os governos futuros, interinos ou não.

\section{REFERÊNCIAS}

ALBUQUERQUE, José Lindomar. Imigração em territórios fronteiriços. In: Congresso Português de Sociologia, 6, 2008, Lisboa. Anais. Lisboa: Universidade Nova de Lisboa, 2008. v. 302, p. 1-13. Disponível em: < http://www.aps.pt/vicongresso/pdfs/302.pdf>. Acesso em: 22 nov. 2014.

ANTECOL, Heather; COBB-CLARK, Deborah A.; TREJO, Stephen J. Selective immigration policy in Australia, Canada, and the United States. Brussels Economic Review, Bruxelas, v. 47, n. 1, p. 45-56, spring 2004. Disponível em: < https:/ / dipot.ulb. ac.be/dspace/bitstream/2013/11915/1/ber-0282.pdf>. Acesso em: 23 nov. 2014.

BECKER, Klaus (Org.). Enciclopédia rio-grandense: Imigração. Canoas: Regional, 1958. $5 \mathrm{v}$.

BRUNO, Marcus. Rio Grande do Sul vai refugiar 33 colombianos ameaçados. 2013. Disponível em: <http://gaucha.clicrbs.com.br/rs/noticia-aberta/rio-grande-do-sul-vairefugiar-33-colombianos-ameacados-7795.html>. Acesso em: 22 nov. 2014.

CANOFRE, Fernanda. Caxias do Sul recebe mais de 320 ganeses em 13 dias na Serra do RS. G1. Porto Alegre, 14 jul. 2014. Disponível em: <http://g1.globo.com/rs/rio-grandedo-sul/noticia/2014/07/ caxias-do-sul-recebe-mais-de-320-ganeses-em-13-dias-na-serrado-rs.html>. Acesso em: 23 nov. 2014. 
CAVALCANTI, Leonardo; OLIVEIRA, Antônio Tadeu Ribeiro de; TONHATI, Tânia. A inserção dos imigrantes no mercado de trabalho brasileiro. Brasília: Observatório das Migrações Internacionais, 2014. 110 p.

CORTES, Kalena E. Are refugees different from economic immigrants?: some empirical evidence on the heterogeneity of immigrant groups in the united states. IZA Discussion Papers, Bonn, v. 1, n. 1063, p. 03-44, mar. 2004. Disponível em: < http:/ ftp.iza.org/ dp1063.pdf>. Acesso em: 23 nov. 2014.

DACANAL, José Hildebrando (Org.). RS: imigração \& colonização. Porto Alegre: Mercado Aberto, 1980. 280 p. (Documenta, 4).

DREHER, Martin Norberto. 190 anos de imigração alemã no Rio Grande do Sul: esquecimentos e lembranças. São Leopoldo: Oikos, 2014. 248 p.

GAUDIOSO, Tomoko Kimura. Os imigrantes japoneses na história do Rio Grande do Sul. In: Simpósio de História da Imigração w Colonização, 17, 2006, São Leopoldo. Anais. São Leopoldo: Oikos, 2008. p. 233-243.

GLUCHOWSKI, Kazimierz. Os poloneses no Brasil: subsídios para o problema da colonização polonesa no Brasil. Porto Alegre: Rodycz \& Ordakowski Editores, 2005. $328 \mathrm{p}$.

INSTITUTO HUMANITAS UNISINOS. Caxias do Sul. Para vereador, senegaleses e haitianos trazem "pobreza”. 2014. Disponível em: <http://www.ihu.unisinos.br/ noticias/529431-caxias-do-sul-para-vereador-senegaleses-e-haitianos-trazem-pobreza>. Acesso em: 19 nov. 2014.

LACZKO, Frank; BRIAN, Tara. North-South migration: A different look at the migration and development debate. 2013. Disponível em: <http://www.iom.int/cms/ en/sites/iom/home/what-we-do/migration-policy-and-research/migration-policy-1/ migration-policy-practice/issues/june-july-2013/northsouth-migration-a-different.html>. Acesso em: 19 nov. 2014.

MELO, Dimas. Comunidade russa do Rio Grande do Sul, Brasil: costumes, tradições e alma russa. Pravda. Moscou, p. 1-3. 08 jun. 2010. Disponível em: < http:/ / port.pravda. ru/russa/08-06-2010/29810-comunidade_russa-0/>. Acesso em: 23 nov. 2014.

NOVAES, Mariana Gonzalez Leandro. Os "galegos da Galícia” no Rio de Janeiro. In: SEMINÁRIO NACIONAL DE MEMÓRIA SOCIAL, 1., 2013, Rio de Janeiro. Anais. Rio de Janeiro: UNIRIO, 2013. p. 1 - 12. Disponível em: <https://www.academia. edu/4399742/OS_GALEGOS_DA_GALÍCIA_NO_RIO_DE_JANEIRO>. Acesso em: 22 nov. 2014.

PAIVA, Ana Lucia Bravo; LEITE, Ana Paula Moreira Rodriguez. Da emigração à imigração?: Por uma análise do perfil imigratório brasileiro nos últimos anos. Ars Historica, Rio de Janeiro, n. 7, p. 1-20, jun. 2014.

PATARRA, Neide Lopes; BAENINGER, Rosana. Mobilidade espacial da população no Mercosul: metrópoles e fronteiras. Revista Brasileira de Ciências Sociais, São Paulo, v. 21, n. 60, fev. 2006, p. 83-102. 
PELLEGRINO, Adela. Drenaje, movilidad, circulación: nuevas modalidades de la migración calificada. 2000. Disponível em: <http://www.cepal.org/celade/proyectos/ migracion/Pellegrino.doc>. Acesso em: 20 nov. 2014.

PIORE, Michael J.. Birds of passage: migrant labor and industrial societies. Nova York: Cambridge University Press, 1979. 229 p.

PREFEITURA DE SÃO PAULO. Dobra o número de migrantes internacionais em São Paulo na última década. 2012. Informes Urbanos No 15. Disponível em: <http:/ / smdu.prefeitura.sp.gov.br/informes_urbanos/pdf/27.pdf>. Acesso em: 19 nov. 2014.

RANINCHESKI, Sonia Maria; UEBEL, Roberto Rodolfo Georg. La acción del Estado brasileño en relación a los migrantes bolivianos en Brasil: la cuestión del trabajo (in) documentado, refugio e inmigración económica. Revista de Estudios Transfronterizos: Si Somos Americanos, Santiago, v. 14, n. 2, p. 47-79, dez. 2014. Disponível em: <http:/ / www.scielo.cl/scielo.php?pid=S0719-09482014000200003\&script=sci_arttext >. Acesso em: 11 jan. 2015.

ROCHA-TRINDADE, Maria Beatriz da. Sociologia das Migrações. Lisboa: Universidade Aberta, 1995. 410 p.

ROLLSING, Carlos; TREZZI, Humberto. Novos imigrantes mudam o cenário do Rio Grande do Sul. Zero Hora. Porto Alegre, 16 ago. 2014. p. 1-7. Disponível em: <http:// zh.clicrbs.com.br/rs/noticias/noticia/2014/08/novos-imigrantes-mudam-o-cenario-dorio-grande-do-sul-4576728.html>. Acesso em: 19 nov. 2014.

SALA, Gabriela Adriana; CARVALHO, José Alberto Magno de. A presença de imigrantes de países do Cone Sul no Brasil: medidas e reflexões. Revista Brasileira de Estudos de População, São Paulo, v. 25, n. 2, p. 287-304, jul. 2008.

UEBEL, Roberto Rodolfo Georg. Análise do perfil socioespacial das migrações internacionais para o Rio Grande do Sul no início do século XXI: redes, atores e cenários da imigração haitiana e senegalesa. 2015. 248 f. Programa de Pós-Graduação em Geografia. Porto Alegre, Universidade Federal do Rio Grande do Sul, 2015. (Dissertação de Mestrado). Disponível em: <http://hdl.handle.net/10183/117357> Acesso em: 17 jun. 2015.

WITTE, Dirce. A colonização holandesa no município de Não Me Toque. 1991. 41 f. TCC (Graduação) - Curso de Geografia, Universidade de Passo Fundo, Porto Alegre, 1991. 